\title{
Sustainable Energy Development Index: A multi-dimensional indicator for measuring sustainable energy development
}

Insah Iddrisu $^{\dagger}$ and Subhes C Bhattacharyya ${ }^{\ddagger}$

(This is the pre-publication version of the paper that has been accepted for publication in Renewable and Sustainable Energy Reviews).

\footnotetext{
${ }^{\dagger}$ Business Development Manager, Deen Petroleum Limited, Accra, Ghana. Email: insahiddrisu@yahoo.com

${ }^{\ddagger}$ Corresponding author. Professor of Energy Economics and Policy, Institute of Energy and Sustainable Development, De Montfort University, The Gateway, Leicester LE1 9BH, UK. Email: subhesb@dmu.ac.uk / subhes bhattacharyya@yahoo.com.
} 


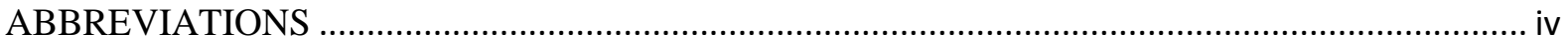

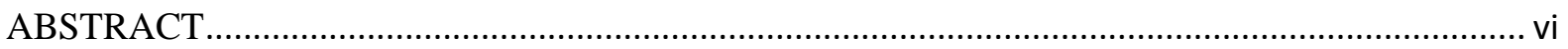

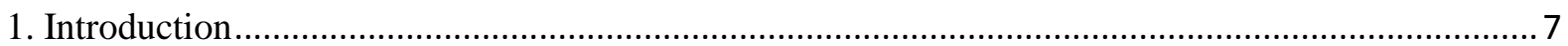

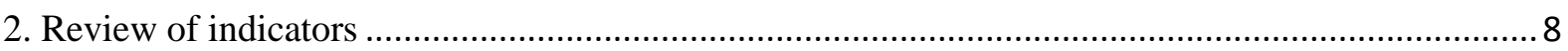

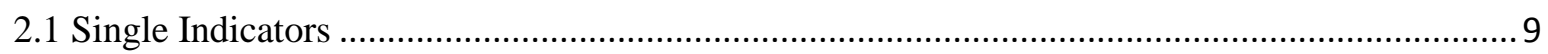

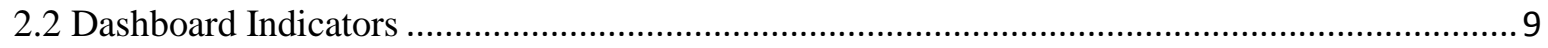

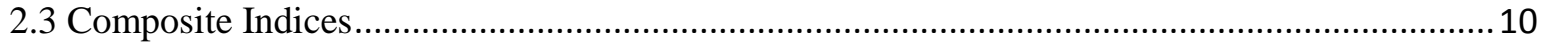

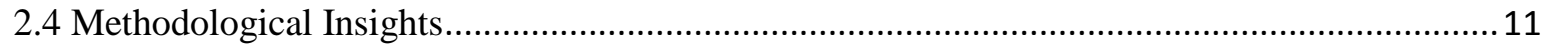

2.5 Review of existing sustainable energy development indicators ................................................ 11

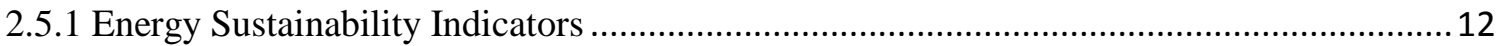

2.5.2 The Energy Indicators for Sustainable Development ….................................................... 13

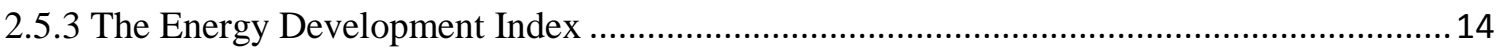

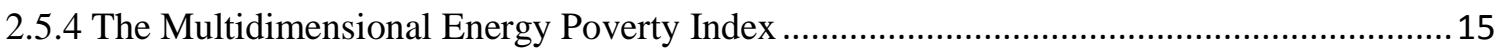

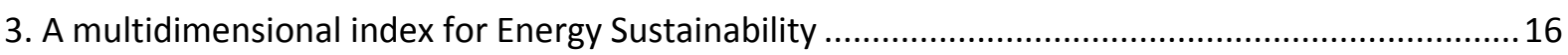

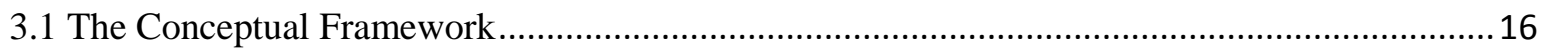

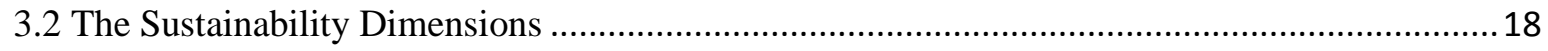

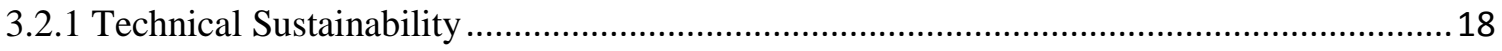

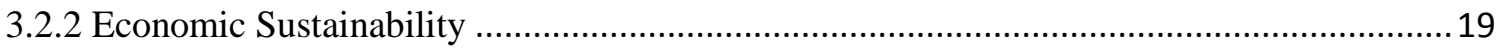

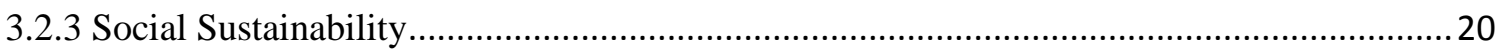

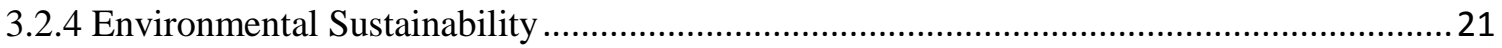

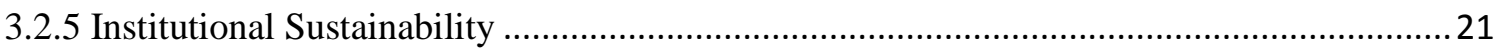

3.3 Synergizing the Sustainability Dimensions with the Conceptual Framework ............................21

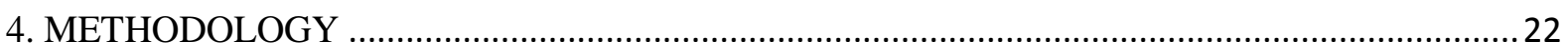

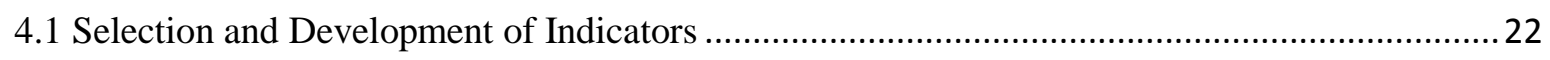

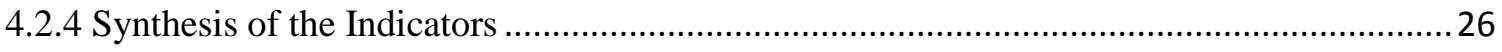

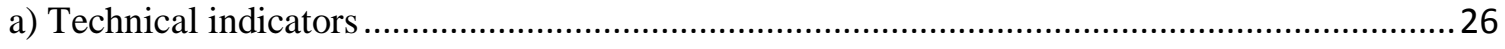

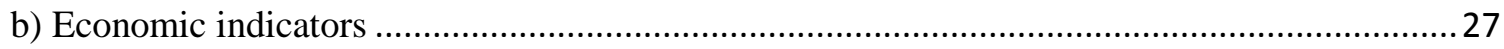

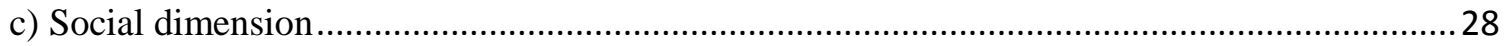

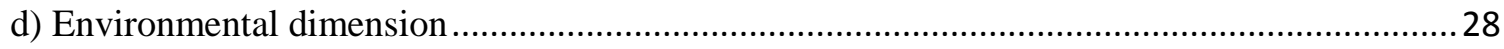

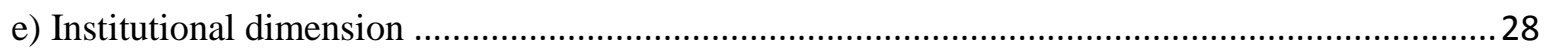

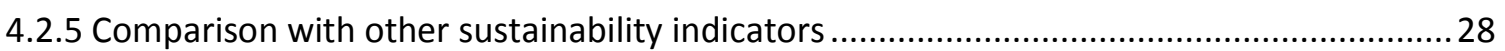

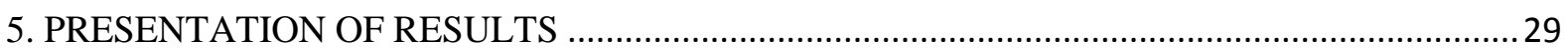

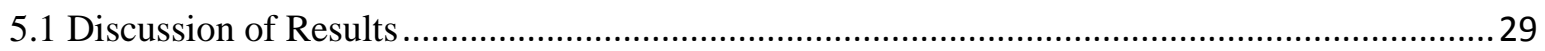

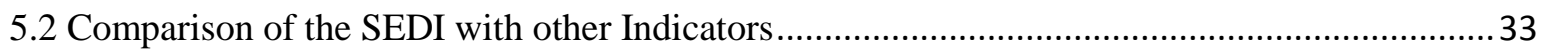


6. CONCLUSION

36

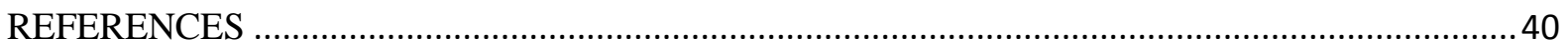

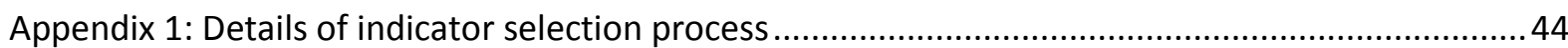

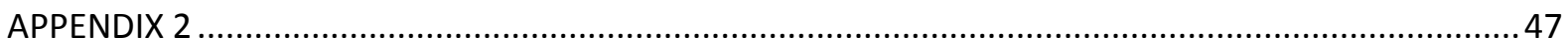




\section{ABBREVIATIONS}

$\mathrm{BP}$

British Petroleum

CDM - $\quad$ Clean Development Mechanism

CERA - - Cambridge Energy Research Associates

CIA - Central Intelligence Agency

$\mathrm{CO} 2 \quad-\quad$ Carbon Dioxide

EDI - $\quad$ Energy Development Index

EISD - - Energy Indicators for Sustainable Development

EPI $\quad$ - $\quad$ Environmental Performance Index

ESI - - Environmental Sustainability Index

ETS - $\quad$ Emissions Trading Scheme

FDI $\quad$ - $\quad$ Foreign Direct Investment

GDP - $\quad$ Gross Domestic Product

GHG - - Green House Gas

GNI $\quad$ - $\quad$ Gross National Income

GNP $\quad$ - $\quad$ Gross National Product

HDI $\quad$ - $\quad$ Human Development Index

IAEA - International Atomic Energy Agency

IEA ETSAP - International Energy Agency Energy Technology Systems Analysis

Program

IEA $\quad$ - International Energy Agency

JI $\quad$ - Joint Implementation

MDGs IP - $\quad$ Millennium Development Goals Indicators Programme

MDGs $\quad$ - $\quad$ Millennium Development Goals

MEPI - $\quad$ Multidimensional Energy Poverty Index

SEDI $\quad$ - $\quad$ Sustainable Energy Development Index

OECD - $\quad$ Organization for Economic Cooperation and Development

PPP $\quad$ - $\quad$ Purchasing Power Parity

TFC $\quad-\quad$ Total Final Energy Consumption

TPES $\quad$ - $\quad$ Total Primary Energy Supply

UNDP - $\quad$ United Nations Development Program

WCED - - World Commission on Environment and Development

WEB - - World Energy Balance

WEO - - World Energy Outlook 
WFB

World Fact Book

WSSD

World Summit on Sustainable Development 


\begin{abstract}
As energy plays a vital role in the modern lifestyle of any country, understanding how sustainable the energy system of a country remains an important policy issue. This paper reviews the comprehensiveness of existing metrics in tracking and tracing energy sustainability and finds that the existing multi-dimensional indicators do not capture the sustainability dimension adequately. This paper proposes a composite index, SEDI (Sustainable Energy Development Index), to fill the gap. SEDI focuses on establishing the sustainability level of both intra- and inter-generational needs. The paper discusses the methodology, data availability and initial country comparisons. It is found that SEDI has a positive correlation with both the Human Development Index (HDI) and the Energy Development Index (EDI) but provides a better understanding of the different dimensions of energy sustainability.
\end{abstract}

Keywords: energy sustainability, index, comparison 


\section{Introduction}

Energy sustainability or more formally energy for sustainable development remains a major challenge for all countries, developed and developing. Although the debate on the appropriate definition of sustainable development continues, the fact remains that our heavy dependence on depletable energy sources cannot be sustained in the long term and continuation on such a path is likely to compromise the ability of the future generations to meet their needs. As energy is an essential input for most economic activities and human well-being, it is therefore imperative to have a clear idea of energy sustainability for policy purposes.

Indicators are widely used as a tool for communicating energy issues to policy makers and the public [5]. A properly designed indicator or set of indicators transforms the basic statistical information to provide a deeper understanding of an issue or dimension and helps develop a clear picture of the whole system, including its inter-linkages and trade-offs [5]. Sustainability related indicators have been developed since the publication of the Brundtland Report in 1987 and various efforts have been made to capture different aspects including energy sustainability dimensions. The international collaborative effort in this respect is documented in [5, 32, 34, 36 and 37] in a great detail.

Despite the proliferation of indicators in the literature, only a few have seen widespread use and recognition. The Human Development Index is perhaps the best known composite indicator used for providing an overall indication of a country's human well-being. Although a number of indicators have emerged in the literature for energy sustainability (as discussed in section 2 below), they are either too difficult to get a clear picture (as in the case of dashboard indicators) or do not capture the sustainability aspect as such (e.g. Energy Development Index of IEA, Multidimensional Energy Poverty Index used in extended HDI) or covers a subset of the sector (e.g. renewable energies only [22- 24] or focuses on an individual country [25-26]. Moreover, based on a detailed review of sustainability indicators Singh et al. [34] assert that most indicators focus on one aspect of sustainability and do not adopt an integrated approach. Further, the existence of a wide variety of indicators suggests uncertainty or ambiguity about the sustainability components, their inter-linkages and the resultant indicators. In the case of energy sustainability, the knowledge gap arises due to incomplete coverage and lack of a systematic focus on sustainability components. This paper presents a composite multi-dimensional index that can be used to analyse sustainable energy 
development using relatively straight-forward information. A comparison of the outcome with a few existing indicators is also presented.

The organisation of the paper is as follows: section 2 presents a review of the existing indicators and presents their limitations; section 3 elaborates the elements of the multidimensional index proposed here and section 4 presents the global picture of energy access using the index while a comparison of the proposed index with other indices is made in section 5. Finally some concluding remarks are provided.

\section{Review of indicators}

Human decision-making often involves changing the existing system or state condition to a desired state [35] and indicators are used as metrics for quantifying and benchmarking progress in these human endeavours. Given that our mental models for understanding how the complex real world works is necessarily incomplete and diverse, "indicators are partial reflections of reality based on uncertain and imperfect models" [35]. As sustainable development refers to the long-term evolution of a complex system, and given the evolving nature of the concept, the desired state remains uncertain but the purpose of indicators is to make the decision-making less risky [35]

Various frameworks have been used to develop sustainable development indicators. The commonly cited frameworks include the following [36]:

a) The Pressure-State- Response (PSR) framework and its variants such as driving forcestate-response (DSR) framework. The PSR framework was adopted by the OECD in its environmental indicator reports while the UN Commission on Sustainable Development used the DSR framework. This framework was originally developed to analyse environmental impacts and relies on the causal linkages to identify drivers and outcomes. However, this framework was abandoned in the sustainability analysis due to its inherent ambiguities and difficulties in linking indicators to the framework.

b) Human or eco-system well-being oriented frameworks - Well-being has different connotations and depending on the perspective taken, the framework can focus on the economic welfare approach (based on utility derived from consumption) or a broader perspective capturing people's feelings, functioning and capabilities [37]; 
c) Issue or theme-based indicators - Here the issues of importance are considered and indicators are developed to capture different issues. They need not be based on any specific conceptual framework;

d) Capital accounting based frameworks - These approaches measure stocks of different types of capital (economic, human, natural and social) and their use for the societal wellbeing.

Moreover, the frameworks can be top-down or bottom-up but a significant domination of the top-down approach can be noticed due to the efforts of international or national bodies in defining and measuring the indicators.

Three broad categories of indicators can be found in the literature: single indicators; group or dashboard of disaggregated individual indicators; and composite indices [1].

\subsection{Single Indicators}

Single indicators provide point values that are simple to interpret than 'dashboard' indicators and also less susceptible to weighting subjectivity biases and other synthesis errors inherent in some composite indices [2]. However, being uni-dimensional, single indicators could present a myopic perspective of the issue or leave out vital information and are therefore not suitable for measuring multidimensional issues like sustainable development or energy access. The $\$ 1$ a day poverty line defined by the World Bank to evaluate absolute poverty and the $10 \%$ cut-off line for household income spent on energy services to define energy poverty are examples of single indicators $[3,4]$.

\subsection{Dashboard Indicators}

In reality, developmental issues are complex and cannot be captured by a single indicator. Such less tangible issues require the use of several variables to capture various components of interactively distinct dimensions. In such cases the appropriate metric must be able to capture and present various components of the issue simultaneously to aid understanding. A variety of dashboard indicators have been offered in the literature for dealing with such issues. Eight energy sustainability indicators proposed by OLADE, ECLAC and GTZ [30] in 1997 is perhaps one of the early set of indicators in energy sustainability. The MDGs Indicators Programme (MDGs IP) [1] proposed 60 indicators. A more recent example 
specific to sustainable energy is the International Atomic Energy Agency's (IAEA) Energy Indicators for Sustainable Development (EISD) [5, 28] where 30 indicators covering the economic, social and environmental dimensions have been developed. Many studies have used EISD or a smaller set of indicators from EISD [e.g. 27 and 29]. This remains popular with many national agencies and policymakers. However, with 60 and 30 indicators respectively for the MDGs IP and EISD, tracking progress or deriving meaningful insights into such large number of indicators can be daunting or impractical. It might even be impossible to do country comparisons or track changes in all indicators. Besides, in reality not all the indicators may be mutually exclusive and tracking them individually with the premise that they are may produce misleading results.

\subsection{Composite Indices}

In an attempt to synergize the strengths and avert the weaknesses of the above category of indicators, composite indices were developed. Composite indices are single easy-to-interpret values like unidimensional indicators whilst at the same time precipitated out of a set of variables that capture the multidimensionality of the issue at hand. They reduce the pool of information that would have been provided by a myriad of dashboard indicators to a level that makes analysis convenient and provides a uniform scale on which comparative performance of countries can be gauged. IISD [36] argue that to measure progress in one or more dimensions of sustainability, an aggregated index is required and the popularity of the ecological footprint, the Human Development Index (HDI), and the Environmental Sustainability Index (ESI) derive from this factor. TSFD [37] however indicate that the composite indicators are more popular in the academic literature and with some NGOs but they have received less patronage of international organisations.

It is possible to follow other categorisation of indicators as well. Patlitzianas et al. [32] present a list of following categories of energy indicators:

1) descriptive indicators such as percentages of energy per fuel;

2) basic normalized indicators such as energy use per GDP or per capita;

3) comparative indicators used to capture the similarity or dissimilarity between two countries;

4) structural indicators capturing the economic structure and its distribution to measure energy system performance; 
5) intensity indicators which measure energy performance of an activity or a system;

6) decomposition indicators that disaggregate the influences of different factors into subcomponents;

7) causal indicators linking influencing causes to energy use;

8) Consequential factors which measure the human factors and energy use link;

9) Physical indicators that use physical outputs or inputs to measure performance.

These indicators generally come under single or dash-board categories indicated before and have the same limitations.

Schipper and Haas [33] suggest the idea of a pyramid of indicators where the most detailed indicators can be at the lowest level and the most aggregated indicators can be at the top. They explain that the hierarchic arrangement allows for a more in-depth analysis to better explain the aggregate changes in energy use. However, the indicators have focused on explaining the change in energy use pattern and not captured the development dimension adequately.

\subsection{Methodological Insights}

The use of composite indicators both in the energy sector and outside it has left a footprint of knowledge pool to be tapped by new metric developers for monitoring, measuring and reporting on sustainable development and energy access. The issues of weight and compensability flaws, synthesis and comparability errors as well as other conceptual and statistical blunders in some composite indices have been extensively discussed in the literature [1, 2, and 6]. A good metric is one that combines a fine blend of statistical robustness, simplicity, transparency, political viability, usefulness to policy design and analysis and above all draws on availability of data.

\subsection{Review of existing sustainable energy development indicators}

Various indicators and indices exist for the measurement of energy access and sustainable energy development. Energy Sustainability Indicators proposed in [30] form a useful policy analysis tool. More recent developments include the Energy Development Index, the Energy 
Indicators for Sustainable Development and the Multi-dimensional Energy Poverty Index. These are discussed below.

\subsubsection{Energy Sustainability Indicators}

OLADE, ECLAC and GTZ [30] present eight indicators to capture energy sustainability taking three each from economic and natural resource dimensions and two for the social dimension. These are as follows:

a) Energy autarky - This means that own energy resources would ensure energy supply over a long time and is measured by the degree of import dependence of a country.

b) Soundness in the face of external changes - This measures economic vulnerability of a country due to changes in the international market conditions. The dependence of a country on oil related income was an issue in Latin America which is reflected through this indicator.

c) Energy productivity - This is the inverse of energy intensity and measures how much output is produced per unit of energy.

d) Electric power coverage - This measures the rate of household electrification.

e) Coverage of basic energy needs - This captures whether households use sufficient quantities of useful energy. This requires information on transformation efficiency of final household energy use.

f) Relative purity of energy use - This measures the carbon di-oxide emissions from energy, with low levels of emissions indicating high sustainability.

g) Use of renewables - The share of renewable energies in the energy mix is measured here.

h) Scope of fossil resources and firewood - This measures the depletion of fossil fuels and firewood considering reserve to production ratio.

The study applied the indicators to Latin American and Caribbean countries to understand the status of energy sustainability in the region. However, no aggregate index was calculated. Sheinbaum-Pardo et al. [31] applied the same set of indicators to analyse the Mexican energy policy and used an equal weighting scheme to arrive at a composite average index. While the above indicators capture important aspects of the energy system, the indicators appear to be arbitrarily chosen and they have not been used to provide a comparative international picture. 


\subsubsection{The Energy Indicators for Sustainable Development}

Specifically designed to capture the provision of energy for sustainable development, the Energy Indicators for Sustainable Development by the IAEA and allied partners is a dashboard of 30 indicators classified into three dimensions of social, economic and environmental sustainability [5]. Table 1 presents the scheme of core EISD indicators.

Table 1: EISD indicator scheme

\begin{tabular}{|l|l|l|}
\hline Social & Economic & Environmental \\
\hline Equity & Use and production & Air \\
Accessibility, & pattern & Climate change \\
Affordability, & Overall use, & Air quality \\
Disparities) & Overall production, & \\
& Supply efficiency, & \\
& Production, end use, & \\
& Diversification, & \\
& Energy prices & \\
\hline Health & Security & Water \\
Safety & Imports & Water quality \\
& Strategic fuel stocks & \\
\hline & & Land \\
& & Soil quality \\
& & Forests \\
& & Solid wastes \\
\hline
\end{tabular}

Source: [29]

Though the indicators may be comprehensive at explaining most aspects of sustainable energy access, the fundamental flaws in dashboard indicators discussed earlier are inherent in the EISD. Tracking or interpreting changes in such vast number of indicators can be a problem. It is also impractical to compare country performance with such set of indicators and the data requirement for some of the indicators such as "contaminant discharges in liquid effluents from energy systems ...", "soil area where acidification exceeds critical load", "rate 
of deforestation attributed to energy use", and the like can be a stumbling block in the evaluation of indicators.

\subsubsection{The Energy Development Index}

The IEA's Energy Development Index (EDI) focuses on a country's or region's transition to the use of modern fuels [7] without reference to whether the transition is sustainable based on the country's economic, social or environmental conditions.

This indicator draws on following four indicators:

a. Per capita commercial energy consumption as an indicator of the overall economic development of a country

b. Per capita consumption of electricity in the residential sector as a metric of electricity reliability and customers' ability to financially access it

c. Share of modern fuels in total residential energy sector consumption to indicate access to modern cooking fuels

d. Share of population with access to electricity

Each indicator is expressed as an index between 0 and 1 using the following formula:

Indicator $=\frac{V_{A}-V_{\text {Min }}}{V_{\text {Max }}-V_{\text {Min }}}$

Where $V_{A}$ is the actual country value, $V_{\text {Min }}$ is the observed minimum value of the indicator for the countries covered and $V_{M a x}$ is the corresponding maximum value. The EDI is then expressed as the arithmetic mean of the four indicators.

As the above variables show, the indicators are output variables measured only at the consumption stage without inclusion of any time dimension. But sustainability requires synergy of both the supply and demand sides of the energy system because limited supply can constrain consumption to values lower than demand. This is actually the main problem for most of the developing countries. Moreover, what happens if a country quickly ramps up its production or import of resources to attain a high rank in the EDI but rapidly falls back due to depletion of local resources or weakening of the economy through increased imports? This sort of indicator therefore does not provide flood warning to the particular country until the flood gate is bridged. What is essentially missing is that it reports a country's output 
without giving a clue as to whether the country's effort is channelled rightly or not such that future consumers could still enjoy similar output.

\subsubsection{The Multidimensional Energy Poverty Index}

A more recent metric proposed for the measurement of energy access is the Multidimensional Energy Poverty Index (MEPI). The MEPI focuses on modern energy deprivation and captures both the incidence and intensity of energy poverty [1]. It is composed of six indicators in five dimensions of basic energy services of cooling, lighting, appliances, entertainment/education and communication in the household. The indicators capture the set of energy deprivations that affect a person in the above dimensions and assign energy poverty to a person if the sum of deprivations exceeds a predetermined value. The MEPI is calculated as a product of the ratio of people categorized as energy poor and their average intensity of deprivation. What this then does is to tell some countries they are energy poor due to direct measurement of useful energy requirements at the various demand sectors of the household and by this much but assigns no reasons to the cause or suggestions as to how the situation can be reversed.

Though it made an attempt to capture the reliability of energy supply as part of deprivation, it does not deal with the issue of sustainability. This means that it also maps performance levels against each other without trying to examine the availability of future supply.

While each indicator reviewed above was created for a specific purpose, they have omitted the energy sustainability dimension. While HDI tries to capture the level of human development, MEPI the level of energy poverty and EDI the energy access dimension, they all tend to ignore the important issue of energy sustainability. These indicators are not specifically designed to capture the sustainability dimension. A country that has high HDI and modern energy access could have very little self-sufficiency (e.g. Japan) and even the domestic resources of a resource rich country could be depleting so quickly it is uncertain how future supplies will be sustained (e.g. Nigeria). Therefore, high HDI or EDI does not necessarily indicate a sustainable energy future. Failure to capture the rate of substitution of exhaustible resources with renewable ones as they are depleted means that such a metric would have left out a vital component of sustainable energy availability. Inversely, a country with a low EDI or MEPI (e.g. Ghana) can still have a moderate level of energy sustainability. Omissions of key causal relationships like this were the Achilles' heel of most past development policies such as the Millennium Development Goals (MDGs). There was over 
indulgence on the end results by policymakers whilst energy, being a foundational intermediate input, was ignored [19]. It is about time then that the missing corner stone of energy sustainability is fixed to complement existing indices for a holistic picture on energy issues.

\section{A multidimensional index for Energy Sustainability}

A simple "Sustainable Energy Development Index (SEDI)" is proposed here to remedy the above issues and is described below.

\subsection{The Conceptual Framework}

We recall that the objective of sustainability is to ensure that the desirable choices of society do not diminish over time, and that the desirable output level is always obtained. Substitutions may occur and the process chain may change over time to reflect progress of needs and experience but in the end future generations should not get fewer options than the present ones [9]. To evaluate the sustainability of an existing energy supply system, therefore, one must first evaluate the process cycle to identify the key nodes (processes) in it. Certain key operations are normally vital to restarting the cycle once the process is completed whilst others within the process chain may also be crucial to ensuring that the process does not terminate immaturely or deliver less value than is required. Once these key nodes in the cycle are identified and their triggers (drivers) or pre-requisites are perpetually provided, the sustainability of the cycle can be guaranteed.

In the case of an energy system, the cycle is in two main parts: the supply side and the demand side as presented by Fig. 1 below. The entry point to this cycle is the production or imports and is one of the key nodes in the cycle. The desirable output is the Total Final Consumption (TFC). However, to obtain this, there must first be an input into the energy supply system in the form of domestic production or imports or both. Because energy can come from different sources requiring different treatment to become the useful TFC, the mixture of production and imports (some of which are still in their primary forms) at this stage called the Total Primary Energy Supply (TPES) must be transformed or converted. Since the amount of TFC obtainable from the TPES depends on the efficiency of conversion, the conversion system also has the ability to determine the final output and is therefore another key node of the cycle. 
Fig. 1: Energy resources flow chart (the energy use cycle)

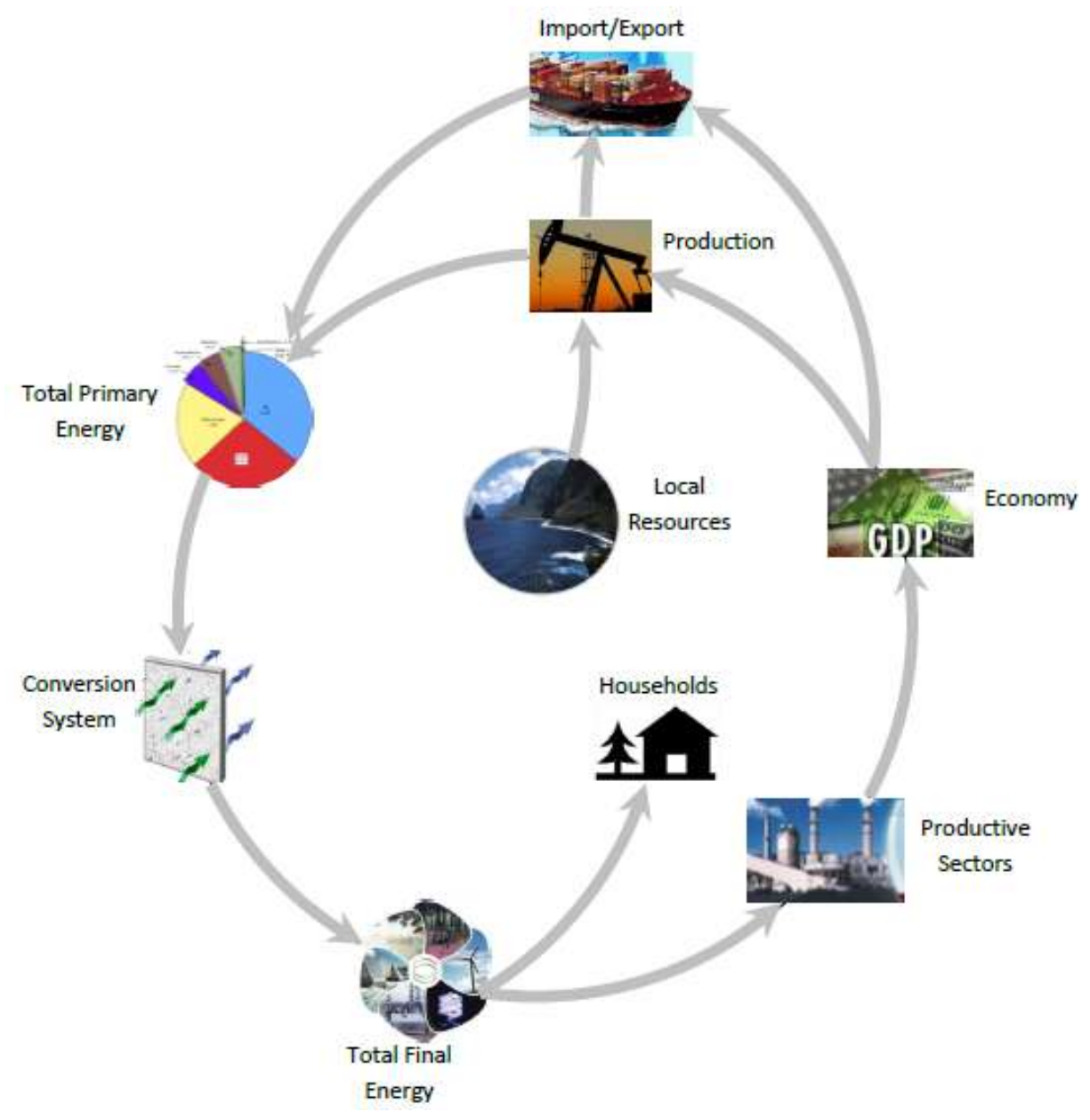

Source: Authors

Once the TFC is obtained, the first half of the cycle (the supply side) is complete. However, to ensure sustainability, there has to be another trigger of the system. Because energy is not the actual desirable need of society but only a means to it, the TFC produced is virtually useless unless it can be used to satisfy the actual useful needs of society. Two distinctions of TFC uses are relevant here to ensuring the continuity of the cycle: a non-productive ('deadload' or 'dead-end') use and a productive (regenerative) use. Non-productive uses of energy occur at the residential sector where energy is used to satisfy needs of physiology and pleasure. Though overall the productive use of energy is salient to ensuring continuity of the cycle, issues of energy access are within the residential domain where poor households struggle for the lower hierarchical energy needs of physiology before progressing towards the self-actualization needs of productive uses. 
Productive use of energy occurs outside households. It is energy used for the purpose of production. This is where rational economic use of energy normally occurs because the target here is the product and the consumption decision will not take place if the benefits of consumption are not more than the costs. It includes energy used for agricultural, industrial, commercial, transport, and official services. The concept is that since financial exchange is required to start the domestic production process or importation of energy goods, the capacity to restart the energy generation cycle largely depends on productivity from the TFC. This has two components: the share of TFC used for productive purposes which eliminates the energy dead loading or non-economic burden (non-productive use) of the country and the energy intensity which defines the productive energy use efficiency. The combination of these two parameters can define the productive capacity of each country per unit of energy consumed.

This productive capacity is very important because it is the parameter that determines the wealth creation (development potential) of each country given a unit of energy. It is also important because each of the starting processes - production and imports - requires some form of financial investment and this can only happen if the TFC produced led to the creation of wealth in the economy some of which is recycled to trigger the cycle. The productive sectors are also therefore a key node in the energy cycle.

\subsection{The Sustainability Dimensions}

Though the concept of sustainable development has been extensively discussed in the literature, it is still an evolving subject where new ideas of sustainability continue to emerge. Aside the three core dimensions of sustainability namely economic, social and environmental; there has also been the definition of the institutional dimension in some literature [5]. In this work, we focus on five dimensions of sustainability, namely technical, economic, social, environmental and institutional [8]. Though other dimensions could still be defined, the above five dimensions give a very strong representation of the multidimensionality of energy sustainability and if, well captured, provides a very strong starting ground for defining sustainable energy access. These are discussed below.

\subsubsection{Technical Sustainability}

This is the supply side of the cycle that captures the ability of the energy supply system to meet the present and future needs of society reliably, efficiently and from clean sources. Technically, the supply system consists of the physical infrastructure that defines the configuration of the system and hence the expected output; and the resources inputs. 
Infrastructure includes, among others, oil production setups, transporting pipelines, refineries, and gasification plants. Resource inputs include the primary energy resources such as crude oil, coal, natural gas, hydro-power, nuclear or renewable energies. The combination of resource inputs and the configuration of the infrastructure define the production capacity of the energy system and thus its ability to meet the needs of the society at any given time. A 'simple machine' mass transfer model is assumed in this study where a unit per capita consumption of TFC by society is dependent on the quantity and quality of inputs as well as the configuration and efficiency of the machine (see Fig. 2 for a schematic diagram). Technical losses occur for some resource types at the input stage through resource depletion and inside the machine (conversion system) through efficiency losses.

Fig. 2: Simple Machine mass transfer model of technical sustainability

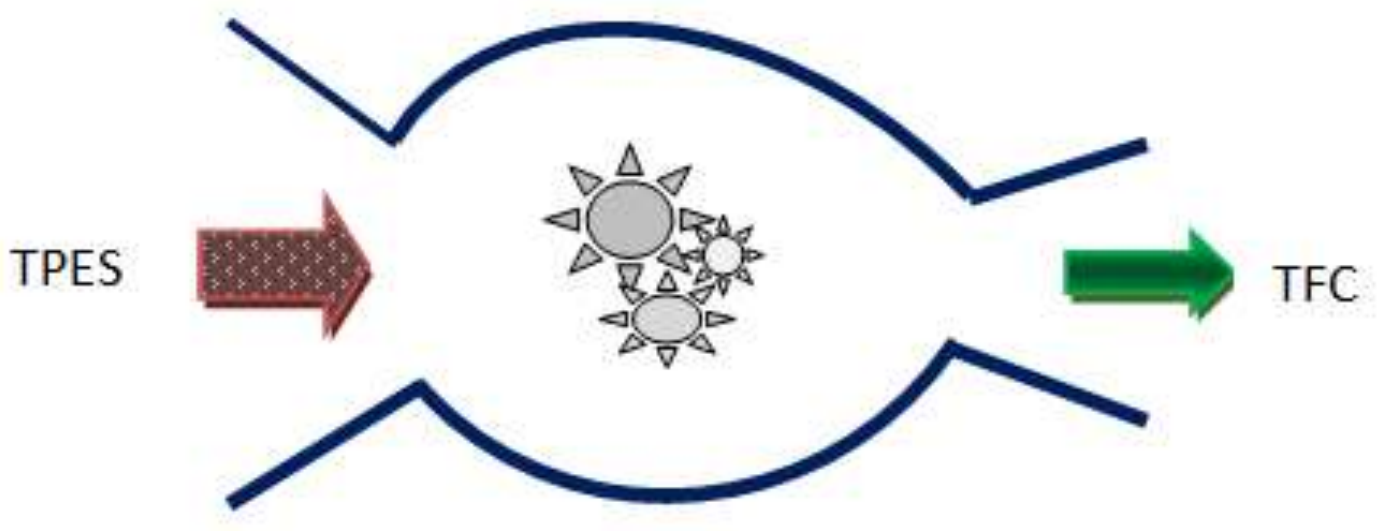

Note: TPES - total primary energy supply; TFC - Total final energy;

\subsubsection{Economic Sustainability}

This dimension evaluates whether the energy supply is cost effective and affordable. Cost effectiveness is required to ensure that energy investments are economically viable to encourage reinvestment in the system which promotes sustainability. Affordability also ensures that the supplied energy is not just physically available but actually accessible to society because they can afford to consume it. The two complement each other to ensure the sustainability of the supply system. If the supplied energy is too costly, society cannot consume it and thus, the suppliers do not get any return for their investment leading to shrinkage or final abandonment of the system.

However, going back to our concept of energy dead loading, we recognize that society consumes energy for both productive and non-productive purposes. Since the consumption of 
modern energy involves financial transaction of one form or another, a household cannot continue to consume energy unless it has a way of getting back some form of income. At the country level, this income can be measured as the Gross National Income (GNI) or GDP and the amount of this wealth that can be created depends on the amount of energy left after nonproductive uses and the efficiency with which it is used. This value creation from the productive use of energy, recycled into household pockets, then sets the whole cycle of production and consumption rolling again. Economic sustainability can therefore be assessed by observing the share of energy used for productive purposes and the efficiency with which the productivity is done. It is important to indicate here that our mental models influence our indicator choice and an optimal resource allocation framework will perhaps try to find out the optimal use of energy to ensure energy sustainability. However, for our given purpose of evaluating the energy sustainability of a given system, the optimal condition of the system is not a prerequisite.

\subsubsection{Social Sustainability}

This sustainability dimension assesses the distributional effect of energy on society. It measures the acceptability and accessibility of energy supply by all of society. Society will accept what it sees as fair and giving equal opportunity to everyone. This has two main subdimensions: spread and financial inclusion. The spread defines the total area of society physically covered by energy services. Grid systems tend to exclude some areas either because they are in remote geographic zones or too expensive for grid extensions. Physical exclusion may also occur due to erratic supply of energy services. On the other hand, portions of society may be physically covered by energy services but still excluded from consuming it financially. This type of exclusion comes from unequal distribution of a country's wealth where a smaller percentage of the population owns a larger portion of its wealth. Recognizing the difficulty in obtaining physical coverage data for each country and the controversies involved in defining which price is affordable to society as normative definitions of basic energy needs are quite controversial, the use of per capita consumption of clean energies and income inequality to capture social sustainability of energy systems is quite appropriate. The former is a lump-sum proxy for both physical and financial access to modern energies whilst the latter is a representation of equity in purchasing power among the population of the country. 


\subsubsection{Environmental Sustainability}

This dimension aims to reduce the negative impact of energy use on society and to extend the positive ones. The environment as the repository of resources and the sink to wastes has the similitude of a chemical reaction in an enclosed system. It is self-controlling: it initially provides the inputs for the reaction to take place. But as the reaction progresses, finite inputs are used up and released wastes start acting as inhibitors to further reaction; slowing it down until it finally comes back to a halt if no external interference is allowed to perpetuate it. Climate change has been largely attributed to the stocks of $\mathrm{CO} 2$ emissions in the atmosphere released by the combustion of fossil fuels [20]. The use of solid fuels at households is also said to be responsible for diseases and deaths through indoor air pollution [21]. It is also responsible for the depletion of some forests. Biodiversity has also suffered serious losses of some species due to oil rig blowouts (e.g. Macondo Well) and fuel tanker accidents (e.g. Exxon Valdez). The list of environmental damage from energy systems is limitless. If the present trend is therefore allowed to continue, a point of self-limitation will be reached where more destruction comes from energy use than benefit.

\subsubsection{Institutional Sustainability}

This defines the level of local participation in the management and control of the energy system and embodies local ownership and participation, local skill base, local regulation and protection of investors and consumers. This is the dimension that defines the system structure and framework of processes and where policy decisions on the future structure are introduced. The institutions defining the industry structure are the tie to the external world and include issues of political stability and foreign policy. A fully deregulated energy industry with investor protection and assured market will attract foreign direct investment (FDI) as well a local participation through partnerships and technology transfer.

\subsection{Synergizing the Sustainability Dimensions with the Conceptual Framework}

To put our energy supply cycle in the perspective of these dimensions, it is realized that the part of the cycle starting from resource inputs (either production of local resources, import of foreign resources or both) through the conversion system to the TFC forms the technical dimension. It determines what amount of energy can be produced from the system at any point in time. For non-productive sectors, the per capita TFC defines the economic dimension. For productive sectors, since the TFC output is not really the desirable need, the 
value created through the use of that energy forms the economic dimension. It informs the overall wealth of society through energy use in both intangible form as non-productive use and valued form such as GNI or GDP as productive use. The manner in which the TFC or its resulting economic output is distributed among society defines the social dimension. The aim here is about equity and fairness leading to acceptability of the system. If the available energy is physically and financially accessible to everyone, then social sustainability is achieved. At each stage of the cycle environmental damages occur due to physical disruption, release of wastes or inevitable losses. The combined effect is that the negative impacts will disrupt sustainable existence of society if the created burden surpasses the natural self-cleansing capacity of the environment. These impacts of energy use on the environment and biodiversity define the environmental dimension of energy use. The institutional dimension basically defines the structure of the system and determines how each of the other four dimensions is managed and controlled to ensure the best blend of benefits and costs. It is the result of the policy path taken and includes issues that relate to local institutional framework e.g. you could have an energy industry that has an open foreign policy which welcomes foreign direct investment (FDI) with a guiding framework of licensing and regulations, and another with a closed door policy where the industry is managed entirely by nationals. Institutional sustainability is achieved irrespective of the industry structure or policy path as long as the management and control ensures that the quantity and quality of energy services required by the society are met at all time.

\section{METHODOLOGY}

\subsection{Selection and Development of Indicators}

Complex issues like sustainable energy include dimensions that are hardly tangible enough to capture with simple indicators. Consequently, a trade-off is required between complexity and ease of use of the indicator so that regular updates can be easily made and meaningful insights can be obtained. Similarly, as an evolving subject, the dimensions are not fixed and it is possible for another set of dimensions to be used to capture the sustainability of energy. However, the indicators chosen for this research represent a good starting point and effort is made to ensure they are as representative of the dimensions to the extent possible. The objective is to define the values of indicators such that each computed dimension can be expressed as a ratio that ranges between zero (0) and one (1). A zero value means no sustainability for that dimension and 1 mean full attainment of sustainability. Though it is 
ensured all fall within 1, a value less than zero can be allowed to mean an unsustainable status for a given dimension. In reality, the dimensions will interact in a complex system that will be difficult to discretely untangle. However, the overall SEDI is simply taken here as the arithmetic mean of the five dimensions of technical (Tec), economic (Eco), social (Soc), environmental (Env) and institutional (Ins) sustainability (see Fig. 3 for a graphical illustration). Expressing indicators in this uniform scalar system allows easy application of basic arithmetic in composing each dimension.

Fig. 3: Illustrative diagram of sustainable energy access

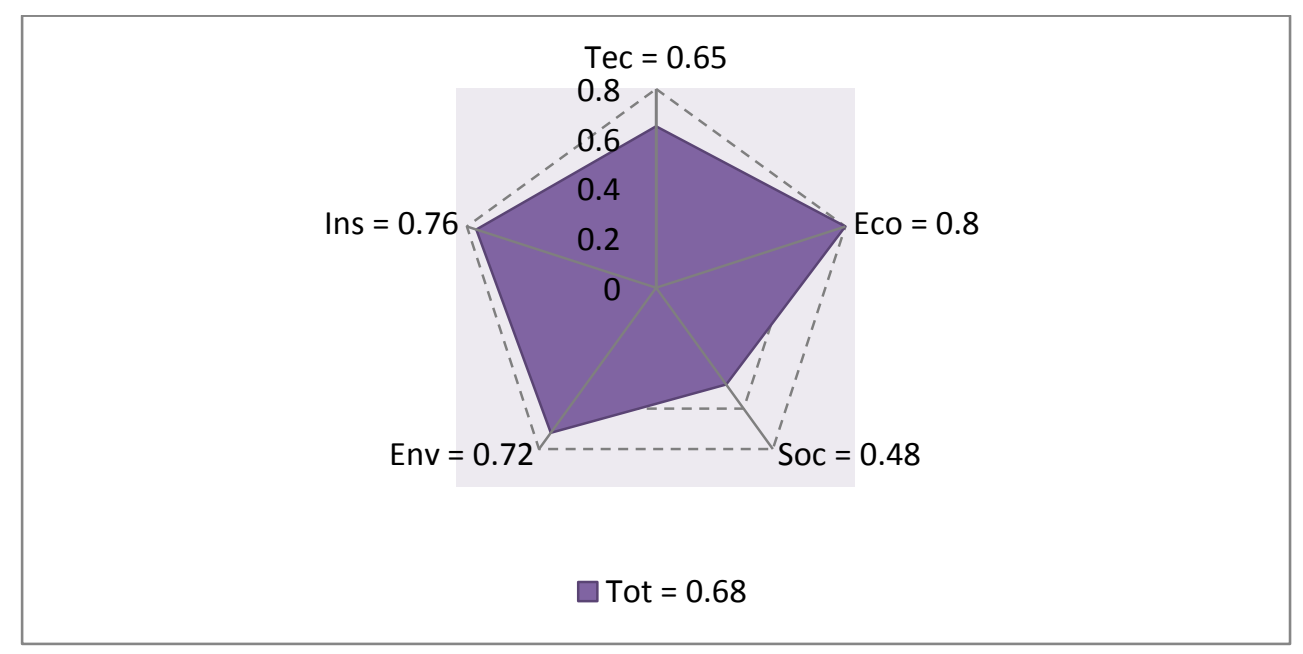

It is possible to adopt other alternative ranking schemes. For example, instead of using a composite index, it is possible to rank countries based on each of the five dimensions retained in our index. However, such one dimensional evaluation defeats the purpose of capturing the overall picture of sustainability. Similarly, it is possible to use Pareto superior criterion wherein Country A is ranked superior to Country B if A does better in all dimensions compared to B. This can be easily implemented from our results presented in the following section but to keep the presentation simple and manageable, only the composite index is presented below.

As was observed in [2], some indicators of sustainable development contain errors in the aggregation process due to non-uniform definition of indicator scales. It is recognizable though that defining indicator boundaries to fit into this sort of scale can be very difficult for some situations e.g. if energy intensity were used as an indicator, what would be the lower or upper limit of the value? In the analysis of the performance of a single country, one could 
compare the value to the previous period but where international comparative analyses of country performances are concerned this becomes problematic. One could use the regional or world average in such situations. However, such averages can be misleading as the average may not represent the desirable value. Averages may be skewed by outliers on the scale making them improper benchmarks on which to measure individual performance; such may not encourage improvement.

In this research, the normalization process used by the UNDP for the calculation of the HDI [9] has been adopted. However, two scenarios of normalization have been defined to suit two directional objectives. For some indicators, the higher the value the better the performance is whilst for some, the converse holds.

If the definition of a directional indicator is such that a higher value is better, the normalization equation is defined as:

$V=\frac{V_{A c t}-V_{\text {Min }}}{V_{\text {Max }}-V_{\text {Min }}}$

Where $\mathrm{V}$ is the indicator value, $\mathrm{V}_{\mathrm{Act}}$ is the actual indicator value for the particular country, $\mathrm{V}_{\text {Min }}$ is the minimum value of the indicator observed in the whole range of countries concerned and $\mathrm{V}_{\mathrm{Max}}$ is the corresponding maximum value.

On the other hand, if the indicator definition is such that the smaller, the better, the normalization equation is modified as:

$V=\frac{V_{\text {Max }}-V_{A c t}}{V_{\text {Max }}-V_{\text {Min }}}$

Where the variables have the same definitions as above

The selection of indicators was also guided by the availability, reliability and consistency of data. Table 2 below provides a summary of the indicator set used in this research. Further details related to the selection process, data requirement and limitations are presented in Appendix 1. The synthesis of indicators in each dimension is discussed in the following section.

Table 2: Set of indicators for sustainable energy development

\begin{tabular}{|l|l|l|l|l|}
\hline Dimension & Code & Indicator & Data Required & Data Source \\
\hline
\end{tabular}




\begin{tabular}{|c|c|c|c|c|}
\hline \multirow{3}{*}{ Technical } & TEC1 & $\begin{array}{l}\text { Share of } \\
\text { depletable (non- } \\
\text { renewable) } \\
\text { energies in TPES }\end{array}$ & $\begin{array}{l}\text { TPES; Total } \\
\text { consumption of non- } \\
\text { renewable energies }\end{array}$ & $\begin{array}{l}\text { IEA, World Energy } \\
\text { Balances, } 2011\end{array}$ \\
\hline & TEC2 & $\begin{array}{l}\text { Depletion } \\
\text { coefficient of } \\
\text { local energy } \\
\text { resources }\end{array}$ & $\begin{array}{l}\text { Domestic production } \\
\text { values of coal, oil, } \\
\text { natural gas and solid } \\
\text { fuels; Proved reserves } \\
\text { of coal, oil, natural } \\
\text { gas; Total forest area; } \\
\text { Total land area }\end{array}$ & $\begin{array}{l}\text { IEA, World Energy } \\
\text { Balances, 2011; } \\
\text { World Bank, World } \\
\text { Development } \\
\text { Indicators (WDIs), } \\
2012\end{array}$ \\
\hline & TEC3 & $\begin{array}{l}\text { Overall system } \\
\text { Conversion } \\
\text { Efficiency }\end{array}$ & TFC; TPES & $\begin{array}{l}\text { IEA, World Energy } \\
\text { Balances, } 2011\end{array}$ \\
\hline \multirow{3}{*}{ Economic } & ECO1 & $\begin{array}{l}\text { Per capita } \\
\text { consumption of } \\
\text { commercial } \\
\text { energies }\end{array}$ & $\begin{array}{l}\text { Total commercial } \\
\text { energy consumption; } \\
\text { Population }\end{array}$ & $\begin{array}{l}\text { IEA, World Energy } \\
\text { Balances, } 2011 \text {; } \\
\text { IEA, World Energy } \\
\text { Indicators, } 2011\end{array}$ \\
\hline & ECO2 & $\begin{array}{l}\text { Final energy } \\
\text { intensity }\end{array}$ & TFC; GDP in PPP & $\begin{array}{l}\text { IEA, World Energy } \\
\text { Balances, } 2011 \text {; } \\
\text { IEA, World Energy } \\
\text { Indicators, } 2011\end{array}$ \\
\hline & ECO3 & $\begin{array}{l}\text { Share of } \\
\text { productive use of } \\
\text { energy }\end{array}$ & $\begin{array}{l}\text { TFC; Residential } \\
\text { Energy Consumption }\end{array}$ & $\begin{array}{l}\text { IEA, World Energy } \\
\text { Balances, } 2011\end{array}$ \\
\hline \multirow[t]{2}{*}{ Social } & SOC1 & $\begin{array}{l}\text { Per capita } \\
\text { consumption of } \\
\text { clean energies in } \\
\text { the residential } \\
\text { sector }\end{array}$ & $\begin{array}{l}\text { Total Clean energy } \\
\text { consumption in the } \\
\text { residential sector; } \\
\text { Population }\end{array}$ & $\begin{array}{l}\text { IEA, World Energy } \\
\text { Balances, } 2011 \text {; } \\
\text { IEA, World Energy } \\
\text { Indicators, } 2011\end{array}$ \\
\hline & SOC2 & Income inequality & Gini coefficient & $\begin{array}{l}\text { CIA, The World } \\
\text { Fact Book, } 2012\end{array}$ \\
\hline Environmental & ENV1 & Share of 'dirty & Total consumption of & IEA, World Energy \\
\hline
\end{tabular}




\begin{tabular}{|c|c|c|c|c|}
\hline & & $\begin{array}{l}\text { fuels' in } \\
\text { residential energy } \\
\text { consumption }\end{array}$ & $\begin{array}{l}\text { 'coal, peat, crude oil, } \\
\text { solid fuels; REC }\end{array}$ & Balances, 2011 \\
\hline & ENV2 & Carbon intensity & $\begin{array}{l}\text { TPES; Total } \mathrm{CO} 2 \\
\text { emissions from fuel } \\
\text { combustion }\end{array}$ & $\begin{array}{l}\text { IEA, World Energy } \\
\text { Balances, } \\
\text { IEA, CO2 emissions } \\
\text { from fuel } \\
\text { combustion, } 2011\end{array}$ \\
\hline Institutional & INS1 & $\begin{array}{ll}\text { Overall } & \text { Self } \\
\text { Sufficiency } & \end{array}$ & $\begin{array}{l}\text { TPES; Indigenous } \\
\text { production }\end{array}$ & $\begin{array}{l}\text { IEA, World Energy } \\
\text { Balances, } 2011\end{array}$ \\
\hline
\end{tabular}

\subsubsection{Synthesis of the Indicators}

\section{a) Technical indicators}

For a unit of depletable energy, the amount left for future use after exhaustion of the annual production is what defines the Technical sustainability of the system after it is adjusted for conversion losses. The assumption here is that since renewable energies do not pose future threats of depletion from consumption except through means other than resource and infrastructure availability, the ability of the system to yield continuously desired options for society is influenced technically by the depletable portion. Therefore, considering a unit of available reserve, the technical sustainability can be synthesized from equation 5 as:

Technical Sustainability $=(1-T E C 1 * T E C 2) * T E C 3$

The term within bracket represents the amount of depletable reserve left after the annual depletion. If the reliance on depletable sources (TEC1) and the rate of depletion of such sources (TEC2) are small and the conversion efficiency (TEC3) is high, the technical sufficiency of the country will be high as well. Evidently, a country with a high share of renewable energy penetration or nuclear energy will require less amounts of non-renewable energy and this ensures technical sustainability. The overall level of technical sustainability is adequately captured through the above formulation although renewable energy share or nuclear share is not explicitly included. 


\section{b) Economic indicators}

The per capita consumption of modern energies (ECO1) defines the overall economic wellbeing potential of each person in the particular country based on the consumption of energy that meets the quality criteria for sustainable development (the issue of distributional effects is dealt with below under the Social Dimension). For optimization of economic benefits from such energy, it must be used efficiently. Thus, the energy intensity (ECO2), which is an inverse of energy use efficiency, if combined with ECO1 will define the gross economic benefit that can be derived from that fraction of 'quality' energy in the TFC per person. The economic value per capita is therefore given by the 'quality' energy consumed times its use efficiency i.e.

Economic benefit per capita $=\frac{E C O 1}{E C O 2}$

Where,

Energy use efficiency $=\frac{1}{\text { Energy intensity }}=\frac{1}{E C O 2}$

To ensure the sustainability of the above development status, financial generation is required. Economic productivity is the engine behind the development that society desires to have good standards of living and is also the source of the financing required to reproduce or import more energy to resuscitate the supply cycle. It is further the source of income for the consumers that will continue to consume the energy and other economic products. If productivity is low and little value is created from the use of energy, society will be less empowered to continue consuming modern energy. Since equation (6) represents an economy wide value, in actual terms part of that benefit is gained as intangible satisfaction of residential needs and the productive portion determines the sustainability of the acquired benefit. Thus,

Economic Sustainability $=\frac{E C O 1 \times E C O 3}{E C O 2}$

Since the resulting answer is not in percentage scale but is such that the higher the better, it is normalized according to equation (2) to conform to the percentage scale for uniformity in the final synthesis of the overall sustainability index. 


\section{c) Social dimension}

The per capita consumption of clean energy (SOC1) concept, though it accounts for physical deprivation to clean energies, fails to account for financial exclusion as it assumes that there is uniform access and actual consumption by everyone. However, this is not the case. Since clean energies are commercial and their consumption requires financial transaction, access to income is a pre-requisite. Meanwhile, income is not uniformly distributed in most countries and only some sections of society are empowered to consume clean energy. To account for the disproportional spread of clean energy consumption power, the per capita consumption is modified with the level of income inequality in the country defined by the Gini Coefficient (SOC2). Equity will foster acceptability among society. The dimension is therefore defined by:

Social Sustainability $=\mathrm{SOC} 1 *(1-\mathrm{SOC} 2)$

Since a high Gini coefficient indicates high inequality, the bracket term defines the actual level of equal distribution of income. The distribution adjusted energy use bears similarity with MEPI but unlike MEPI, our indicator is not just limited to energy poverty dimension alone.

\section{d) Environmental dimension}

The sustainability of the dimension is simply the product of the two indicators i.e.

Environmental sustainability $=$ ENV1 x ENV2

However, since for both indicators the smaller the better, the resulting product is normalized according to equation (2) to fall within a percentage scale desired for compiling the overall sustainability index.

\section{e) Institutional dimension}

Since this dimension was represented by a single indicator, the indicator value also defines the Institutional Sustainability. However, to ensure that all values fall within 0 and 1 , the indicator was normalized according to equation 1.

\subsubsection{Comparison with other sustainability indicators}

The indicator presented here covers five dimensions capturing sustainable development of the energy sector. The aggregation used in SEDI follows the logic used in HDI (as is used in 
MEPI and EDI). But in terms of focus, HDI, EDI and MEPI do not capture the same dimensions as SEDI. HDI does not consider any energy dimension. EDI focuses on energy use taking per capita commercial energy and electricity use into consideration. SEDI covers commercial and renewable energies but does not focus on energy consumption alone. MEPI focuses on energy poverty alone and accordingly, it differs from SEDI in its focus.

\section{PRESENTATION OF RESULTS}

\subsection{Discussion of Results}

To test its global applicability, the SEDI was calculated for all countries for which appropriate data could be obtained for 2009 and Figure 4 below shows the top 20 country rankings of SEDI on a global application basis. The year 2009 was chosen because that is the year for which data for most of the indicators that depend on IEA data are available. Data that could not be obtained in the required year such as fossil (coal, oil and natural gas) reserves were adjusted using production values of adjacent years to correspond to 2009. 
Fig.4: Top 20 country rankings by SEDI on a global basis

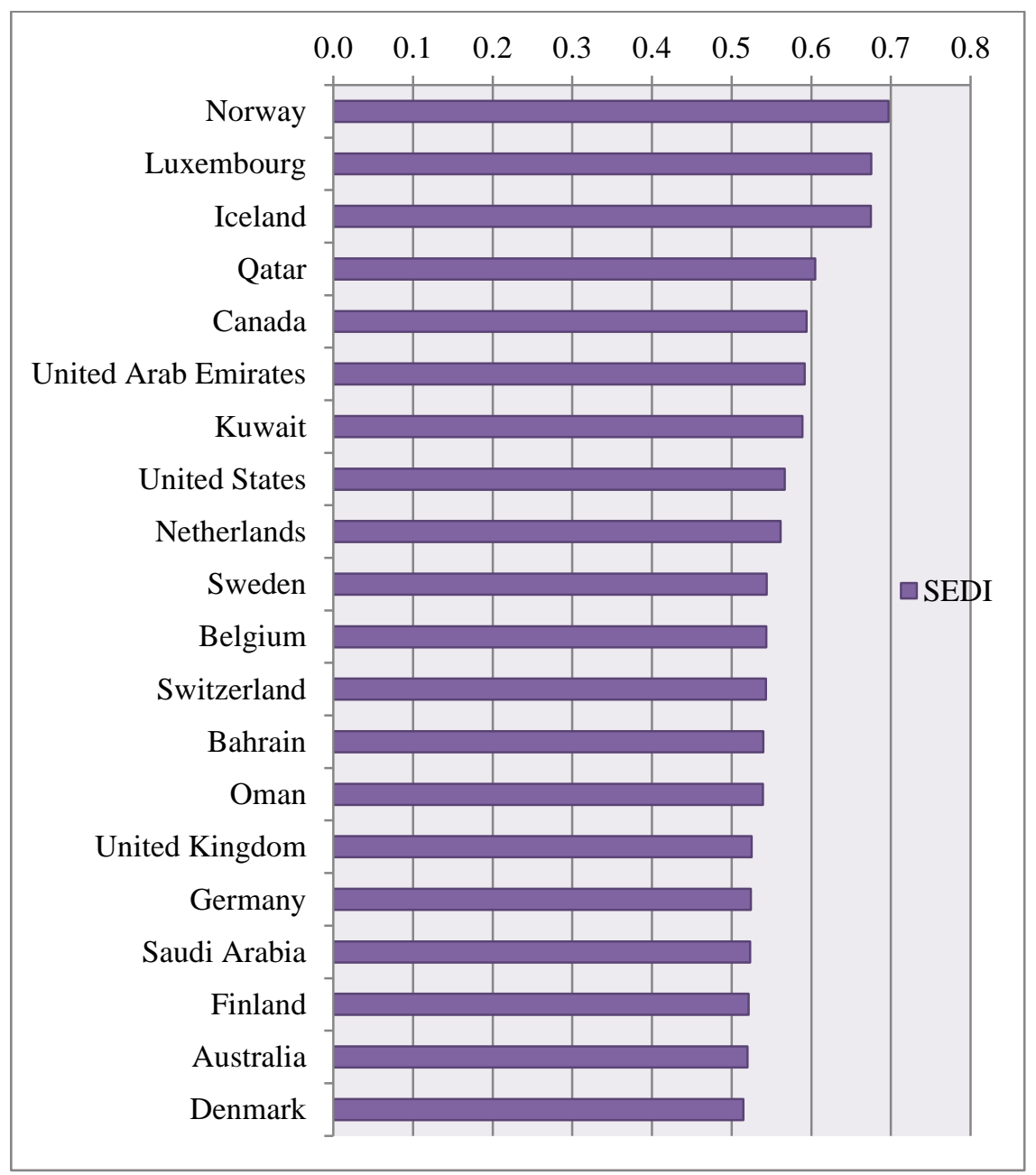

Clearly, not only is the nexus between energy access and development reflected here but also a link between development and access sustainability. Most of the above countries are members of the OECD.

However, since energy access is normally the problem of the developing and least developed countries, the SEDI analysis was focused on that area and calculated for those countries included in the EDI and for which data was available. The top 20 rankings of the result are presented in table 3 below and the full list in Appendix 2.

Table 3: Country ranking of developing countries by the SEDI

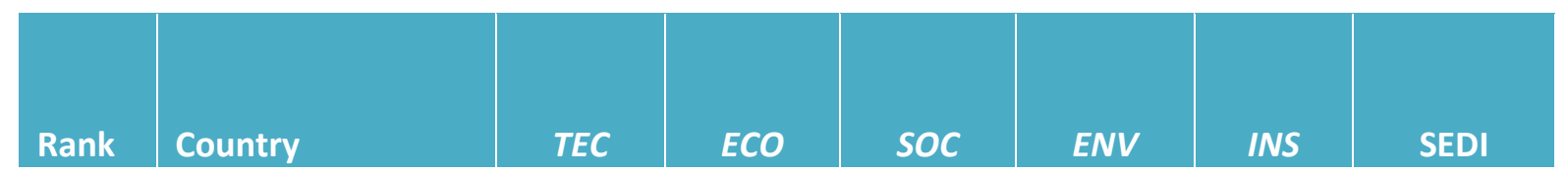




\begin{tabular}{|c|c|c|c|c|c|c|c|}
\hline 1 & Iran & 0.918 & 0.469 & 1.000 & 1.000 & 0.147 & 0.707 \\
\hline 2 & Argentina & 0.884 & 1.000 & 0.397 & 0.978 & 0.098 & 0.671 \\
\hline 3 & Libya & 0.784 & 0.790 & 0.346 & 0.877 & 0.391 & 0.638 \\
\hline 4 & Algeria & 0.842 & 0.365 & 0.412 & 0.993 & 0.350 & 0.593 \\
\hline 5 & Venezuela & 0.869 & 0.500 & 0.268 & 0.962 & 0.278 & 0.575 \\
\hline 6 & Jordan & 0.844 & 0.385 & 0.296 & 0.997 & 0.001 & 0.505 \\
\hline 7 & Congo & 0.910 & 0.031 & 0.015 & 0.543 & 1.000 & 0.500 \\
\hline 8 & Gabon & 0.995 & 0.058 & 0.088 & 0.647 & 0.694 & 0.496 \\
\hline 9 & Ecuador & 0.967 & 0.284 & 0.155 & 0.814 & 0.219 & 0.488 \\
\hline 10 & Malaysia & 0.822 & 0.783 & 0.131 & 0.580 & 0.121 & 0.487 \\
\hline 11 & Colombia & 0.897 & 0.495 & 0.077 & 0.674 & 0.284 & 0.486 \\
\hline 12 & Angola & 0.952 & 0.044 & 0.031 & 0.611 & 0.779 & 0.483 \\
\hline 13 & Brazil & 0.931 & 0.448 & 0.097 & 0.796 & 0.086 & 0.471 \\
\hline 14 & Syria & 0.826 & 0.263 & 0.173 & 1.000 & 0.094 & 0.471 \\
\hline 15 & Egypt & 0.828 & 0.278 & 0.210 & 0.929 & 0.110 & 0.471 \\
\hline 16 & Costa Rica & 0.879 & 0.552 & 0.093 & 0.764 & 0.048 & 0.467 \\
\hline 17 & Lebanon & 0.528 & 0.320 & 0.528 & 0.911 & 0.000 & 0.458 \\
\hline 18 & Yemen & 0.887 & 0.058 & 0.072 & 1.000 & 0.183 & 0.440 \\
\hline 19 & Uruguay & 0.594 & 0.596 & 0.198 & 0.707 & 0.032 & 0.426 \\
\hline 20 & Cuba & 0.809 & 0.527 & 0.138 & 0.559 & 0.042 & 0.415 \\
\hline
\end{tabular}

Source: Authors' calculation

Even among this category, most of the countries at the top are the better-off among the developing economies. But just like any performance indicator, the SEDI is a snapshot of countries on a comparative scale of relative sustainability and the significance of its value should be interpreted with circumspection. At the aggregate level, one may be tempted to think that a country with high value of SEDI should be more developed than others with lower values. However, a disaggregated look at the various components of the index is further required to gain full insight into an individual country's ability to transform such an advantageous position into development. The technical weakness in most of the countries is attributed not mainly to the depletion of non-renewable resources but to over dependence on their forest resources which threatens the sustainability of future access in two ways. First, the move to renewable sources, either due to climate change pressure or depletion of fossils, will require biomass sources to play an important role in energy access in the far future and second, the depletion of forest resources removes the carbon sequestration role of plants and will accelerate the climate change effect. It will also rid some living species of their natural habitat; loss of biodiversity. In addition, a country could have attained higher SEDI in a particular year because it has just improved its technical sustainability with newly discovered 
resources; but because the access is only a stimulus for development, tangible economic and social gains may still be lagging behind the attained access.

Further, a country needs to be able to link the various sectors of sustainability together to realize the benefits of energy consumption. The link is especially strong for those countries which have high productive uses of energy and are efficient in energy use such that their economic and social dimensions of sustainability are well developed. This explains why some countries are able to achieve high economic growth under relatively low energy access than others as was highlighted in the energy access programmes and sustainable development study [8]. Countries with high performance in only one or two dimensions tend to rank lower than those with a relatively uniform dimensional spread of sustainability.

Moreover, a country may actually be developing more socially and economically than another (e.g. China than Cameroon in the HDI ranking) but still has a lower value of SEDI because of its high carbon emissions. Because the impacts of emissions are long term and not felt immediately, the temptation is to imagine that such a country has a higher sustainable energy system since it provides its society with better sustained access in the short to medium run.

Finally, resource rich countries perform better in energy access than their resources poor counterparts if the institutional framework is effective, all other things being equal. Revenue gains through exports help provide society with the income it needs to consume modern energy and because the resources are also locally owned, even if they are produced through FDI or managed by external investors, the value created for the resource and the industry created leads to economic benefits for local resource owners and industry employees.

Consider Fig. 5 below which shows the performance of Algeria and China on the five dimensions of sustainability. Though according to the HDI Algeria is just a little developed than China, the SEDI ranks China far lower because it performs poorly in the social, environment and institutional dimensions due to its higher population density, higher carbon intensity and lower self-sufficiency. A careful study of the SEDI can therefore be used to guide policy path in the effort to link the social and economic dimensions of energy sustainability to the other dimensions to accelerate development. 
Fig. 5: Comparison of Algeria and China based on multi-dimensional sustainability

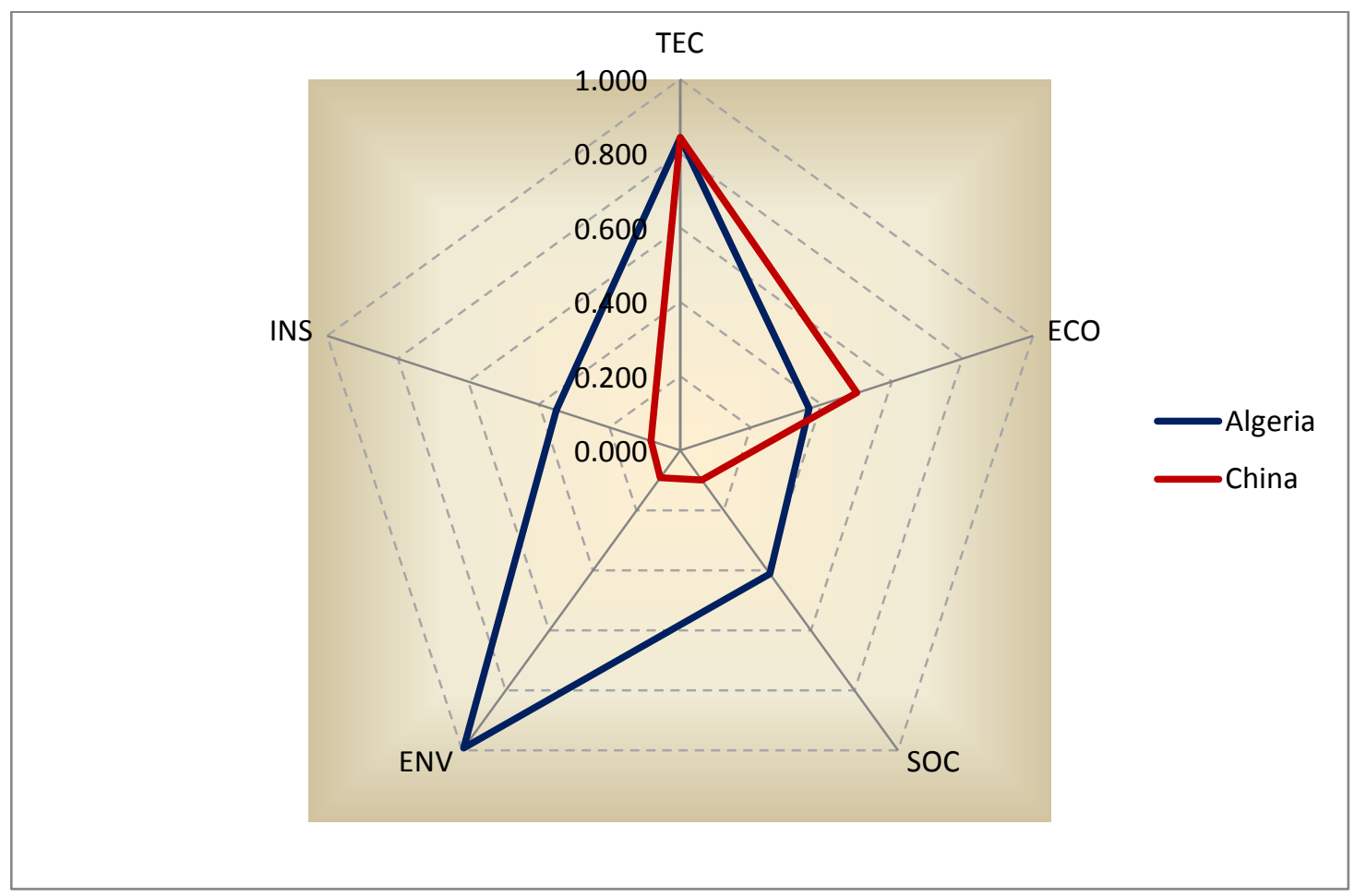

Source: From table 3

\subsection{Comparison of the SEDI with other Indicators}

The result of the SEDI was also compared with the HDI, the EDI and the MEPI. It is important though to understand the conceptual difference between the SEDI and these indicators. The EDI tries to monitor a country's transition to modern cooking energy and electricity over time by giving a snapshot of the level of access to these fuels and the level of economic development indicated by the per capita consumption levels at any particular time. The HDI is non-energy focused and is more interested in the economic and social development level of the particular country whilst the MEPI estimates the degree of deprivation of households to modern fuels and electricity. All the above indicators are output based models that are only interested in availability of the final consumable modern energy to society and therefore rely on only the demand side variables. The SEDI, in trying to add the time dimension of energy access to the metrics, aims at measuring each country's ability to ensure that this level of access by the present generation does not erode the ability of the country to supply the future generations with same or better level of access. It therefore evaluates the time availability of both input and output variables. Built to incorporate three of 
the four indicators of the EDI, the SEDI is positively correlated with the EDI but varies from it significantly due to the inclusion of several indicators not captured in the EDI. The SEDI also gives an indication of human development in a country and is positively correlated to the HDI. A comparative analysis of the four indicators is illustrated by figure 6 (a) to (d).

Fig. 6: Comparative trends of the SEDI with HDI, EDI and MEPI
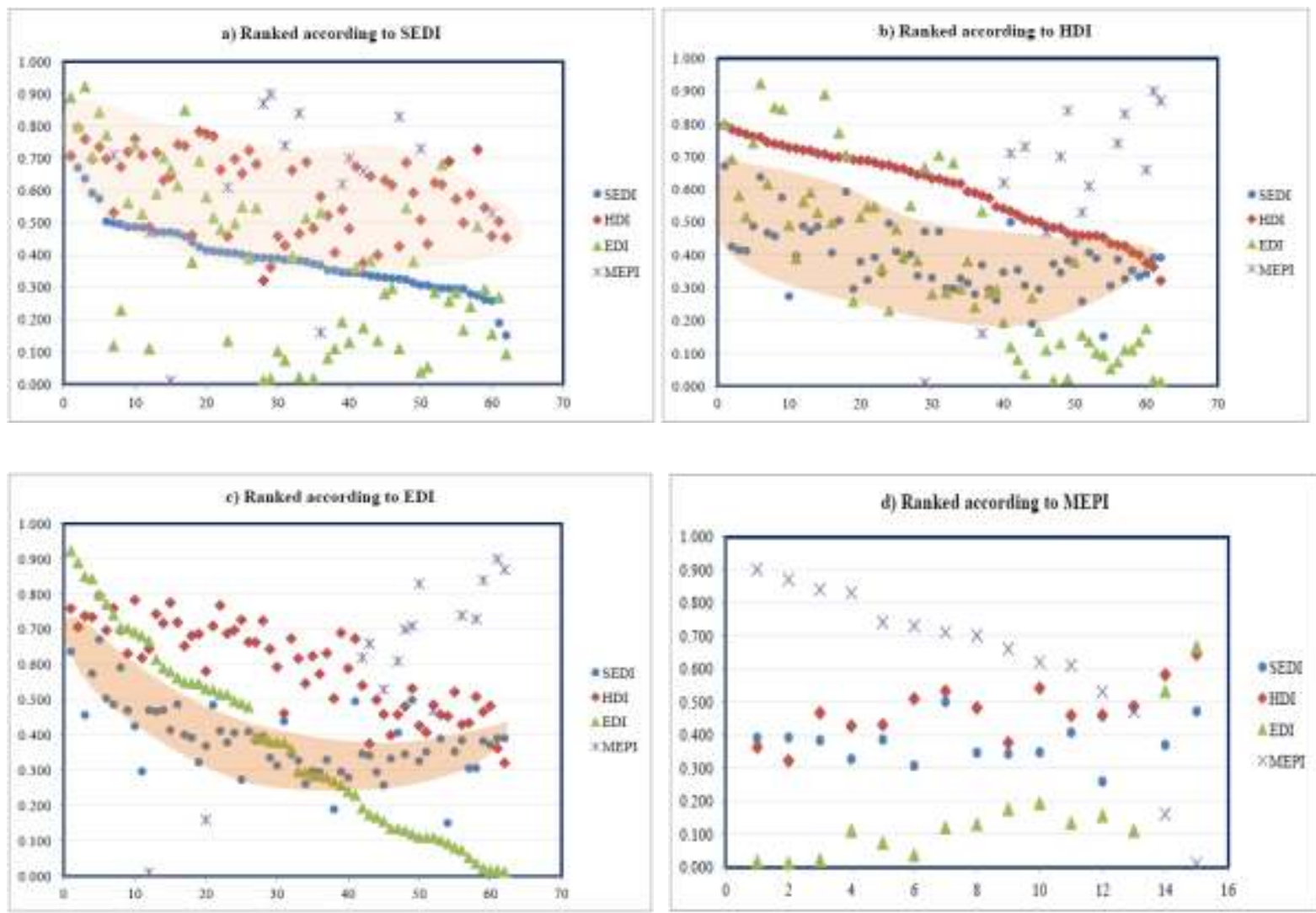

Figure 6(a) shows that the SEDI basically dissects the EDI values indicating a co-integration of some sort. It also demonstrates that countries that have been able to sustain high energy access have also achieved high human development and the two fall together, albeit at different slopes. In 6(b), it is observed that the HDI, EDI and SEDI again show a positive correlation though at differing slopes and at lower HDI values, the gradient of fall of the SEDI tends to reduce. This is because, at high development, the energy demand is also high as more people attain access to modern energy. At that stage, due to resource strain, energy access becomes more delicate to sustain and development and energy access tend to become more co-integrated; changes in one affects the other. However, at low levels of development, most of the poor countries have still not exploited their energy potential from local resources and sustainability of present access levels become less difficult to attain. Another reason is that, most of the poor countries rely hugely on traditional sources of energy which are not 
linked with development. So, the country may have a high technical sustainability because of large biomass (e.g. forest) reserves even though the economic and social dimensions of sustainability may be very small. Similar explanations can be attributed to 6(c) where, again, the SEDI falls as the EDI reduces but changes slope as smaller values of EDI are reached. In 6(d) where the ranking is done according to the MEPI, it is seen that both the HDI and the SEDI move together. Because the SEDI is designed to include both access and sustainable part of energy, at higher values of energy poverty (MEPI), SEDI is small and consequently, human development (HDI) is also low. As the energy deprivation reduces towards $0 \%$, more access is obtained and sustained which fosters high human development as well.

A further comparative placement of developing countries by the various indicators is shown in table 4 below. Countries are simply ranked according to each indicator and divided into four classes of proportional sizes namely "very high performers", "high performers", "moderate performers" and "weak performers". Again, the indicators correlate better at the higher performance level due to similar reasons cited above. Only the first and last categories are shown. The full list is found in Appendix 2.

Table 4: Comparison of country rankings between the SEDI and HDI, EDI and EPI

\begin{tabular}{|c|c|c|c|c|c|c|c|}
\hline \multicolumn{2}{|c|}{ SEDI } & \multicolumn{2}{|c|}{ HDI } & \multicolumn{2}{|c|}{ EDI } & \multicolumn{2}{|c|}{ EPI } \\
\hline \multicolumn{8}{|c|}{ VERY HIGH PERFORMERS } \\
\hline Iran & 0.707 & Argentina & 0.797 & Libya & 0.923 & Costa Rica & 0.690 \\
\hline Argentina & 0.671 & Uruguay & 0.783 & Iran & 0.889 & Malaysia & 0.625 \\
\hline Libya & 0.638 & Cuba & 0.776 & Lebanon & 0.850 & Colombia & 0.623 \\
\hline Algeria & 0.593 & Panama & 0.768 & Venezuela & 0.844 & Brazil & 0.609 \\
\hline Venezuela & 0.575 & Malaysia & 0.761 & Argentina & 0.798 & Ecuador & 0.606 \\
\hline Jordan & 0.505 & Libya & 0.760 & Jordan & 0.773 & Thailand & 0.600 \\
\hline Congo & 0.500 & Costa Rica & 0.744 & Malaysia & 0.741 & Nicaragua & 0.592 \\
\hline Gabon & 0.496 & Lebanon & 0.739 & Algeria & 0.706 & Nepal & 0.580 \\
\hline Ecuador & 0.488 & Venezuela & 0.735 & Syria & 0.703 & Panama & 0.579 \\
\hline Malaysia & 0.487 & Jamaica & 0.727 & Uruguay & 0.692 & Gabon & 0.579 \\
\hline Colombia & 0.486 & Peru & 0.725 & South Africa & 0.681 & Philippines & 0.574 \\
\hline Angola & 0.483 & Ecuador & 0.720 & Egypt & 0.668 & Uruguay & 0.571 \\
\hline Brazil & 0.471 & Brazil & 0.718 & Costa Rica & 0.616 & Argentina & 0.565 \\
\hline Syria & 0.471 & Colombia & 0.710 & Brazil & 0.590 & Cuba & 0.565 \\
\hline Egypt & 0.471 & Iran & 0.707 & Cuba & 0.581 & Sri Lanka & 0.557 \\
\hline Costa Rica & 0.467 & Tunisia & 0.698 & Ecuador & 0.563 & Venezuela & 0.556 \\
\hline \multicolumn{8}{|c|}{ WEAK PERFORMERS } \\
\hline Vietnam & 0.314 & Tanzania & 0.466 & Congo & 0.120 & Mongolia & 0.454 \\
\hline Kenya & 0.307 & Yemen & 0.462 & Benin & 0.110 & Cameroon & 0.430 \\
\hline
\end{tabular}




\begin{tabular}{|l|r|l|r|l|r|l|r|}
\hline Togo & 0.306 & Senegal & 0.459 & Sudan & 0.110 & Syria & 0.428 \\
\hline Honduras & 0.298 & Nigeria & 0.459 & Angola & 0.110 & Iran & 0.427 \\
\hline South Africa & 0.298 & Nepal & 0.458 & Nepal & 0.102 & Bangladesh & 0.426 \\
\hline Sri Lanka & 0.296 & Haiti & 0.454 & Haiti & 0.093 & China & 0.422 \\
\hline Guatemala & 0.295 & Togo & 0.435 & Cambodia & 0.081 & Jordan & 0.422 \\
\hline Bangladesh & 0.295 & Zambia & 0.430 & Zambia & 0.074 & Haiti & 0.412 \\
\hline Nicaragua & 0.280 & Benin & 0.427 & Togo & 0.053 & Nigeria & 0.401 \\
\hline Jamaica & 0.274 & Sudan & 0.408 & Kenya & 0.037 & Pakistan & 0.396 \\
\hline India & 0.262 & Cote d'Ivoire & 0.400 & Tanzania & 0.022 & Libya & 0.377 \\
\hline Senegal & 0.258 & Zimbabwe & 0.376 & Myanmar & 0.018 & India & 0.362 \\
\hline Pakistan & 0.190 & Ethiopia & 0.363 & Ethiopia & 0.017 & Yemen & 0.355 \\
\hline Haiti & 0.151 & Mozambique & 0.322 & Mozambique & 0.013 & South Africa & 0.346 \\
\hline
\end{tabular}

Source: SEDI (calculated by authors); HDI (World Bank, 2011); EDI (IEA, 2011), EPI (Yale

University, 2012).

Most of the country placements, if not within the same bracket, are often in the adjacent category. The lower correlation at the bottom can however be explained by the fact that the variables often used to compile energy access indicators are based on energy access data that is readily available for the high performers (relatively developed countries). On the other hand the data accuracy from the least developed countries can be a major cause for disparity in indicator values as database organizations tend to estimate some of this data if the country fails to submit the actual or the county itself, due to lack of finances for proper survey may tend to submit estimated data rather than the actual. Thus, indicators dependent on different access variables may entail varying degrees of errors.

\section{CONCLUSION}

Energy poverty has been a chronic canker resident among large proportions of the global population that robs them of any noticeable socio economic development. Whether the underpinning role of energy access to human development has been wrongly diagnosed by policymakers in the past or simply underestimated, energy poverty has metastasized into a malignant tumour that the world finds difficult to remove today. Some past policies e.g. the use of consumer subsidies have failed and some present ones such as the use of off-grid distributed renewable technologies have not achieved much either. Sometimes the right surgical tools are not fully known and even where they are, property rights and priority issues stand in the way. As IEA estimated, an investment rate 5 times the present will be required to achieve universal energy access by the year 2030 [7]. The bitter pill to swallow is that even if this money could be found, the motivation to invest it will be an even bigger hurdle. Most of 
the energy-poor locations of the globe (Africa and Developing Asia) are also the poverty stricken economies. With their current levels of productivity, it is not a misplaced judgment to assume that much of the needed financing will need to come from the developed economies. The prying question then is: what will motivate those countries to invest such large chunks of money for other's benefit?

The consequent issue to deal with therefore is policy priority. Will energy access ever receive the same priority as the now centre-stage climate change issues on the energy policy agenda of the developed countries? Perhaps the declaration of 2012 as the year for universal energy access for all [16] has exhumed the hidden crisis of energy poverty for proper post-mortem in search of an antidote. However, for the appropriate policies to be determined and to be properly targeted there is the need for a robust set of metrics on energy access. Such toolbox of metrics will highlight important progress made by countries towards achieving universal energy access targets and will also help to compare individual country performances.

The existing metrics on energy access and human development have in different ways tried to measure and compare countries based on the rate of energy access they have been able to attain, without assessing how the given access has been achieved or how the present consumption will impact on future supplies. They do not identify good or bad policies to inform future policy path; they simply record the final outcome. Thus, such metrics give flood warning only after the flood gate has been bridged. It is only when a country, high on rank of the metric, suddenly starts to fall due to depletion of local resources or increased vulnerability from increased imports that one realizes the policy path had been wrong.

The multidimensional Sustainable Energy Development Index (SEDI) is the bridge for this analytical gap on energy access. It is designed to rate countries based on their sustainability of energy system. Thus, it has the ability to give a forewarning to a country. By incorporating five sustainability dimensions (technical, economic, social, environmental and institutional), it gives an indication beforehand how a country is performing on various dimensions of development and whether the present level of development can be maintained in the future. The technical dimension measures the ability to maintain the needed total final energy for society at all times and is an evaluation of the sustainability of the energy resource inputs and the energy infrastructure. The economic dimension, by incorporating the share of modern energy in the final consumption, indicates the level of modern energy access by society such as in the case of the EDI. When modified by the share of productive use of energy, the 
economic dimension gives an indication of how society channels the supplied energy into economic productivity after non-productive uses. The social dimension evaluates the social acceptability of the energy access system. If there is a high social aversion for a policy it cannot be said to be sustainable; it will eventually change and the change could be unsustainable. This dimension measures fair and equitable distribution of the available energy as well as wealth created from its use among society. What is seen as fair and giving equal opportunity to everyone will be acceptable to society. The environmental dimension estimates the environmental impact from energy use. Environmental impact comes from both intentional disposal of wastes and unavoidable losses in the energy supply and use chain. Environmental disruption from energy use is threatening the very existence of the lifeline needs such as clean air and water. Finally, the institutional dimension records the precipitate result of the complex interaction of domestic and external factors that impact on the energy supply system. It is a measure of how controllable and manageable the supply is locally by showing how sufficient a country is in producing its own energy needs.

As if by confirmation of the energy-development nexus, Norway and other OECD countries dominated the top 20 list of the SEDI ranking when applied on a global scale. However, the main analysis was focused on the developing countries where energy access issues are more pertinent. It was found that the SEDI is positively correlated with both HDI and the EDI but negatively correlated with the MEPI (built to be opposite to HDI and EDI). The nexus between the indicators was stronger at high levels of development and access as at such levels the link between development and energy consumption become more pronounced due to strain on energy resources and sustainability becomes a delicate issue to grapple with. At lower levels of consumption, the energy system gains more resilience to sustain the given level of access but at that level, most of the consumed energy is either not suited for human development or is less used for productive purposes. Hence the link between sustainable energy access and development becomes weaker. Most of the Sub-Saharan Africa and South Asia countries dangle at the bottom of the SEDI and other indicators as they have limited energy access and development as well.

It is important to caution that the SEDI is not immune to the inherent weakness of 'masking effect' in most aggregate statistics where strong performances of some variables tend to conceal the weaknesses of other variables. A look at the overall SEDI value alone may therefore give a false sense of achievement to some countries such as Angola and Congo. The SEDI value needs to be understood as a relative value whose full implication at the individual 
country level should be derived from analysis of the various dimensions of sustainability. Though Angola and Gabon fall within "very high performers" category of the developing country rankings, they both have very low economic and social sustainability and are therefore low on the human development ladder.

So, if a country studies the performance of the individual dimensions under the SEDI, it will be able to identify policy paths to improving weaker dimensions that can help optimize the socio economic benefits derived from sustainable energy access. Over time, a decomposition of the index along the dimensions could reveal insights into the various aspects of energy supply that improves energy sustainability. Thus, overall, the SEDI can be a good addition to sustainable energy metrics toolbox on the path to sustainable development. 


\section{REFERENCES}

[1] Nussbaumer P, M Bazilian, V. Modi. Measuring energy poverty: Focusing on what matters. Renew Sust Energ Rev 2012; 16(1): 231-43.

[2] Bohringer C, P Jochem. Measuring the immeasurable - a survey of sustainability indices. Ecol Econ 2007; 63(1): 1-8.

[3] Bazilian M, P Nussbaumer, A Cabraal, R Centurelli, R Detchon, D Gielen, H Rogner, M Howells, H McMahon, V Modi, N Nakicenovic, B O’Gallachoir, M Radka, K Rijal, M. Takada and F Ziegler. Measuring energy access: Supporting a global target. The Earth Institute, Columbia University, New York, USA, 2010.

[4] Barnes DF, B Singh and X Shi. Modernising energy services for the poor: A World Bank Investment Review - Fiscal 2000-2008. World Bank Energy Sector Management Program, 2010, World Bank, Washington D.C.

[5] International Atomic Energy Association, Energy Indicators for Sustainable Development: Guidelines and Methodologies, 2005

[6] Mayer AL. Strengths and weaknesses of common sustainability indices for multidimensional systems. Environ Int 2008; 34(2): 277-91.

[7] International Energy Agency. World Energy Outlook, 2011, Paris.

[8] Bhattacharyya SC. Energy access programmes and sustainable development: A critical review and analysis. Energ Sust Dev 2012; 16(3): 263-71.

[9] Klugman J, F Rodriguez and H-J Choi. The HDI 2010: New controversies, Old critiques, Human Development Research Paper 2011/01, 2011, United Nations Development Programme, New York.

[10] International Energy Agency. World Energy Balances 2011, Paris.

[11] International Energy Agency. CO2 Emissions from Fuel Combustion, 2011, Paris.

[12] World Bank. World Development Indicators. 2012, Washington D.C.

[13] United Nations Development Programme. Human Development Report 2011 Sustainability and Equity: A Better Future for All, 2011, New York. 
[14] Yale University, 2012, Environmental Performance Index, EPI Rankings, http://epi.yale.edu/epi2012/rankings, (last visited on $27^{\text {th }}$ July, 2012).

[15] The World Fact Book, 2012, Country comparison: Distribution of family income - Gini Index, $\quad$ CIA, $\quad$ https://www.cia.gov/library/publications/the-worldfactbook/rankorder/2172rank.html, ((last visited $23^{\text {rd }}$ July, 2012).

[16] Ban Ki-Moon, 2012, The Secretary General's High-Level Group on Sustainable Energy for all, United Nations, http://www.un.org/wcm/content/site/sustainableenergyforall/home, (last visited on $23^{\text {rd }}$ July, 2012).

[17] IEA, 2011, The Energy Development Index, International Energy Agency, Paris http://www.worldenergyoutlook.org/resources/energydevelopment/theenergydevelopmentind ex/, ((last visited on $23^{\text {rd }}$ July, 2012).

[18] Index Mundi, 2011, Country Comparison, http://www.indexmundi.com/g/r.aspx?v=69, (last visited $17^{\text {th }}$ July, 2012).

[19] Practical Action, 2009, Energy Poverty: The hidden crisis, The Schumacher Centre for Technology and Development, Warwickshire, United Kingdom.

[20] Dieter Helm and Cameron Hepburn, 2011, The economics and politics of climate change, Oxford University Press Inc., New York.

[21] IEA, 2009, World Energy Outlook, International Energy Agency, Paris.

[22] Liu G. Development of a general sustainability indicator for renewable energy systems: a review. Renew Sust Energ Rev 2014; 31:611-21.

[23] Kurka T, D Blackwood. Participatory selection of sustainability criteria and indicators for bioenergy developments, Renew Sust Energ Rev 2013; 24: 92-102.

[24] Onat N, H Bayar. The sustainability indicators of power production systems. Renew Sust Energ Rev 2010; 14: 3108-15.

[25] Kumar D, SS Katoch. Sustainability indicators for run-of-the river (RoR) hydro projects in hydro rich regions of India. Renew Sust Energ Rev 2014; 35:101-108.

[26] Tsai WT. Energy sustainability from analysis of sustainable development indicators: A case study in Taiwan. Renew Sust Energ Rev 2010; 14:2131-38. 
[27] Mandelli, S, J Barbieri, L Mattarolo and E Colombo. Sustainable Energy in Africa: A comprehensive data and policies review. Renew Sust Energ Rev 2014; 37: 656-686.

[28] Vera, I and L Langolis. Energy indicators for sustainable development. Energy 2007; 32:875-882.

[29] Streimikiene, D and G Sivickas. The EU energy policy indicators framework. Environment International 2008; 34:1227-1240.

[30] OLADE, ECLAC and GTZ. Energy and Sustainable Development in Latin America and the Caribbean: Approcahes to energy policy. Latin American Energy Organisation (OLADE), 1997 (see http://repositorio.cepal.org/handle/11362/30858 accessed on 6th March, 2015).

[31] Sheinbaum-Pardo, C., BJ Ruis-Mendoza and V Rodriguez-Padilla. Mexican energy policy and sustainability indicators. Energy Policy 2012; 46:278-83.

[32] Patlitzianas, KD, H Doukas, AG Kagiannas and J Psarras. Sustainable energy policy indicators: Review and recommendations. Renewable Energy 2008; 33: 966-73.

[33] Schipper, L and R Haas. The political relevance of energy and CO2 indicators - An introduction. Ener Policy 1997; 25:639-649.

[34] Singh RK, HR Murty, SK Gupta and AK Dikshit. An overview of sustainability assessment methodologies. Ecol Indicators 2012; 15:281-299.

[35] Meadows, D., 1998. Indicators and Information Systems for Sustainable Development - A Report to the Balaton Group. The Sustainability Institute, Hartland, USA (http://www.iisd.org/pdf/s_ind_2.pdf accessed on 8 March 2015).

[36] Pinter L, P Hardi and P Bartelmus, Sustainable Development Indicators: Proposals for a way forward, International Institute for Sustainable Devleopment, 2005

(https://www.iisd.org/pdf/2005/measure_indicators_sd_way_forward.pdf, last accessed $8^{\text {th }}$ March 2015).

[37] Joint UNECE/ Eurostat/ OECD Task Force on Measuring Sustainable Development, TSFD, Frameworks and suggested indicators to measure sustainable development, May 2013, 
(http://www.unece.org/fileadmin/DAM/stats/documents/ece/ces/2013/SD_framework_and_in dicators_final.pdf, last accessed on $30^{\text {th }}$ April, 2015). 


\section{Appendix 1: Details of indicator selection process}

\begin{tabular}{|c|c|c|c|c|}
\hline Dimension & Indicator & Purpose & Relevance & Indicator definition \\
\hline Technical & $\begin{array}{l}\text { Share of } \\
\text { depletable } \\
\text { energies in PES } \\
\text { (TEC1) }\end{array}$ & $\begin{array}{l}\text { To measure the rate of } \\
\text { transition to renewable } \\
\text { sources of energy }\end{array}$ & $\begin{array}{l}\text { To reduce the risk of sustainability } \\
\text { due to depletion therefore, a country } \\
\text { must transit from depletable sources } \\
\text { to renewable sources in time. }\end{array}$ & $\begin{array}{l}\text { this indicator is defined by the total share of } \\
\text { depletable and conditionally depletable resources in } \\
\text { an energy supply system. It is measured by dividing } \\
\text { the total sum of depletable and conditionally } \\
\text { depletable energies by the TPES. The higher the } \\
\text { share, the higher the sustainability risk of the supply } \\
\text { system. }\end{array}$ \\
\hline & $\begin{array}{l}\text { Depletion } \\
\text { coefficient of } \\
\text { local energy } \\
\text { resources } \\
\text { (TEC2) }\end{array}$ & $\begin{array}{l}\text { To monitor the rate at } \\
\text { which local non-renewable } \\
\text { resources of energy are } \\
\text { depleting }\end{array}$ & $\begin{array}{l}\text { This indicator is especially critical } \\
\text { for conditionally depletable energies } \\
\text { whose sole renewability depends on } \\
\text { how quickly they are consumed } \\
\text { compared to the speed at which they } \\
\text { are renewed. }\end{array}$ & $\begin{array}{l}\text { It is measured as the weighted average of all the } \\
\text { non-renewable sources of energy in the domestic } \\
\text { production. For depletable sources (fossils), the } \\
\text { depletion coefficient, } \mathrm{d}_{\mathrm{i}} \text { is simply defined as: } \\
d_{i}=\frac{P_{i}}{R_{i}} \text { where } \mathrm{P} \text { and } \mathrm{R} \text { represent the production and } \\
\text { reserves of a given source. } \\
\text { For conditionally depletable resources like biomass } \\
\text { which depend on land for regeneration, } \\
d_{i}=\frac{\text { Rate of consumption }}{\text { Rate of regeneration }} \cong \frac{\text { Biomass use intensity }}{\text { Forest density }}= \\
\frac{P_{b} / P}{T F A} / T L A \\
\text { Where } \mathrm{Pb} \text { is biomass production, } \mathrm{P} \text { is total energy } \\
\text { production, TFA is total forest area and TLA is }\end{array}$ \\
\hline
\end{tabular}




\begin{tabular}{|c|c|c|c|c|}
\hline Dimension & Indicator & Purpose & Relevance & Indicator definition \\
\hline & & & & total land area. \\
\hline & $\begin{array}{l}\text { Overall system } \\
\text { conversion } \\
\text { efficiency } \\
\text { (TEC3) }\end{array}$ & $\begin{array}{l}\text { To track the improvement } \\
\text { in the technology of } \\
\text { primary energy conversion } \\
\text { of a country }\end{array}$ & $\begin{array}{l}\text { Low conversion efficiency implies } \\
\text { that more of the resource is required } \\
\text { to satisfy same level of useful energy } \\
\text { requirement than that required for a } \\
\text { high efficiency. }\end{array}$ & $\begin{array}{l}\text { This indicator is captured by dividing the TFC of a } \\
\text { country by its TPES. }\end{array}$ \\
\hline \multirow[t]{3}{*}{ Economic } & $\begin{array}{l}\text { Per capita } \\
\text { consumption of } \\
\text { modern energies } \\
(\text { ECO1) }\end{array}$ & $\begin{array}{l}\text { To monitor a country's } \\
\text { progress towards the } \\
\text { provision of clean energies } \\
\text { as an indicator of } \\
\text { improvement in overall } \\
\text { sustainable economic } \\
\text { development potential. }\end{array}$ & $\begin{array}{l}\text { Achievement of the MDGs is } \\
\text { contingent upon the provision of } \\
\text { modern energies. }\end{array}$ & $\begin{array}{l}\text { Measurement of the indicator is by dividing the } \\
\text { total modern energy consumption (MEC) by the } \\
\text { population of the particular country. }\end{array}$ \\
\hline & $\begin{array}{l}\text { Final Energy } \\
\text { Intensity } \\
(\mathrm{ECO} 2)\end{array}$ & $\begin{array}{l}\text { To monitor progress in the } \\
\text { energy use efficiency of a } \\
\text { country }\end{array}$ & $\begin{array}{l}\text { The sustainability goal for each } \\
\text { country is to reduce energy intensity } \\
\text { (promote energy efficiency) which } \\
\text { will increase resource lives and } \\
\text { enhance the profitability of } \\
\text { productive sectors through reduced } \\
\text { consumption of energy for the same } \\
\text { level of output. }\end{array}$ & $\begin{array}{l}\text { The final energy intensity of a country is measured } \\
\text { by dividing the TFC by the economic output of the } \\
\text { country (in purchasing power parity). }\end{array}$ \\
\hline & $\begin{array}{l}\text { Share of } \\
\text { productive use } \\
\text { of energy } \\
\text { (ECO3) }\end{array}$ & $\begin{array}{l}\text { To monitor the influence of } \\
\text { energy supply on a } \\
\text { country's economic growth. }\end{array}$ & $\begin{array}{l}\text { Increasing the productive use of } \\
\text { energy to generate more value will } \\
\text { uplift the economic status of the } \\
\text { country and enable more consumers } \\
\text { to experience the trickledown effect } \\
\text { of such gains empowering them to } \\
\text { access modern energy. }\end{array}$ & $\begin{array}{l}\text { This indicator is measured by deducting the } \\
\text { residential use of energy from the TFC of a country. } \\
\text { The remaining productive use is then expressed as a } \\
\text { ratio of the TFC. }\end{array}$ \\
\hline Social & $\begin{array}{l}\text { Per capita } \\
\text { consumption of } \\
\text { electricity and } \\
\text { modern cooking } \\
\text { energy in the }\end{array}$ & $\begin{array}{l}\text { To track the access, } \\
\text { reliability of, and } \\
\text { household ability to pay for } \\
\text { electricity and modern } \\
\text { cooking fuels. }\end{array}$ & $\begin{array}{l}\text { The use of unclean energies in } \\
\text { households is responsible for severe } \\
\text { chronic health issues and accelerated } \\
\text { mortality and hence not sustainable. }\end{array}$ & $\begin{array}{l}\text { It is estimated by dividing the total household } \\
\text { consumption of clean energies by the population of } \\
\text { the particular country. }\end{array}$ \\
\hline
\end{tabular}




\begin{tabular}{|c|c|c|c|c|}
\hline Dimension & Indicator & Purpose & Relevance & Indicator definition \\
\hline & $\begin{array}{l}\text { residential } \\
\text { sector (SOC1) }\end{array}$ & & & \\
\hline & $\begin{array}{l}\text { Income } \\
\text { inequality } \\
\text { (SOC2) }\end{array}$ & $\begin{array}{l}\text { to monitor the social } \\
\text { acceptance of the energy } \\
\text { access system. Society will } \\
\text { accept what it sees as fair } \\
\text { and equitable. }\end{array}$ & $\begin{array}{l}\text { Lack of modern energy access due to } \\
\text { income inequality leaves some } \\
\text { sections of the society with little } \\
\text { development and low level of living } \\
\text { standards. }\end{array}$ & $\begin{array}{l}\text { The World Bank's Gini Coefficients by country } \\
\text { from the CIA World Fact Book (WFB) was used. }\end{array}$ \\
\hline \multirow[t]{2}{*}{ Environmental } & $\begin{array}{l}\text { The share of } \\
\text { dirty fuels in } \\
\text { residential } \\
\text { energy } \\
\text { consumption } \\
\text { (ENV1) }\end{array}$ & $\begin{array}{l}\text { To monitor the level of } \\
\text { deprivation of households } \\
\text { to clean cooking fuels. }\end{array}$ & $\begin{array}{l}\text { Lack of clean energies leaves huge } \\
\text { portions of the global population still } \\
\text { dependent on traditional solid fuels. }\end{array}$ & $\begin{array}{l}\text { The indicator is measured by summing up the total } \\
\text { consumption of solid fuels as well as crude oil and } \\
\text { dividing it by the residential energy consumption } \\
\text { (REC). }\end{array}$ \\
\hline & $\begin{array}{l}\text { Carbon intensity } \\
\text { (ENV2) }\end{array}$ & $\begin{array}{l}\text { To track improvement in } \\
\text { the emission efficiency of } \\
\text { energy consumption at the } \\
\text { residential level. }\end{array}$ & $\begin{array}{l}\text { Carbon intensity is used here as the } \\
\text { proxy for all emissions from } \\
\text { residential energy combustion. } \\
\text { Countries that are more carbon } \\
\text { intensive are less environmentally } \\
\text { sustainable. }\end{array}$ & $\begin{array}{l}\text { The carbon intensity is defined by dividing the total } \\
\text { CO2 emissions from energy combustion by the } \\
\text { TPES. }\end{array}$ \\
\hline
\end{tabular}




\section{APPENDIX 2}

Table A2: Ranking of Countries according to the sustainable energy development indicator, SEDI

\begin{tabular}{|c|c|c|c|c|c|c|c|}
\hline Rank & Country & TEC & ECO & SOC & ENV & INS & SEDI \\
\hline 1 & Iran & 0.918 & 0.469 & 1.000 & 1.000 & 0.147 & 0.707 \\
\hline 2 & Argentina & 0.884 & 1.000 & 0.397 & 0.978 & 0.098 & 0.671 \\
\hline 3 & Libya & 0.784 & 0.790 & 0.346 & 0.877 & 0.391 & 0.638 \\
\hline 4 & Algeria & 0.842 & 0.365 & 0.412 & 0.993 & 0.350 & 0.593 \\
\hline 5 & Venezuela & 0.869 & 0.500 & 0.268 & 0.962 & 0.278 & 0.575 \\
\hline 6 & Jordan & 0.844 & 0.385 & 0.296 & 0.997 & 0.001 & 0.505 \\
\hline 7 & Congo & 0.910 & 0.031 & 0.015 & 0.543 & 1.000 & 0.500 \\
\hline 8 & Gabon & 0.995 & 0.058 & 0.088 & 0.647 & 0.694 & 0.496 \\
\hline 9 & Ecuador & 0.967 & 0.284 & 0.155 & 0.814 & 0.219 & 0.488 \\
\hline 10 & Malaysia & 0.822 & 0.783 & 0.131 & 0.580 & 0.121 & 0.487 \\
\hline 11 & Colombia & 0.897 & 0.495 & 0.077 & 0.674 & 0.284 & 0.486 \\
\hline 12 & Angola & 0.952 & 0.044 & 0.031 & 0.611 & 0.779 & 0.483 \\
\hline 13 & Brazil & 0.931 & 0.448 & 0.097 & 0.796 & 0.086 & 0.471 \\
\hline 14 & Syria & 0.826 & 0.263 & 0.173 & 1.000 & 0.094 & 0.471 \\
\hline 15 & Egypt & 0.828 & 0.278 & 0.210 & 0.929 & 0.110 & 0.471 \\
\hline 16 & Costa Rica & 0.879 & 0.552 & 0.093 & 0.764 & 0.048 & 0.467 \\
\hline 17 & Lebanon & 0.528 & 0.320 & 0.528 & 0.911 & 0.000 & 0.458 \\
\hline 18 & Yemen & 0.887 & 0.058 & 0.072 & 1.000 & 0.183 & 0.440 \\
\hline 19 & Uruguay & 0.594 & 0.596 & 0.198 & 0.707 & 0.032 & 0.426 \\
\hline 20 & Cuba & 0.809 & 0.527 & 0.138 & 0.559 & 0.042 & 0.415 \\
\hline 21 & Panama & 0.910 & 0.514 & 0.097 & 0.527 & 0.017 & 0.413 \\
\hline 22 & Paraguay & 0.962 & 0.117 & 0.077 & 0.755 & 0.142 & 0.410 \\
\hline 23 & Nigeria & 0.992 & 0.001 & 0.008 & 0.842 & 0.192 & 0.407 \\
\hline 24 & Tunisia & 0.851 & 0.427 & 0.149 & 0.532 & 0.076 & 0.407 \\
\hline 25 & Mongolia & 0.913 & 0.163 & 0.278 & 0.438 & 0.216 & 0.402 \\
\hline 26 & Peru & 0.989 & 0.359 & 0.061 & 0.493 & 0.086 & 0.397 \\
\hline 27 & Thailand & 0.875 & 0.486 & 0.076 & 0.475 & 0.053 & 0.393 \\
\hline 28 & Mozambique & 0.935 & 0.006 & 0.000 & 0.909 & 0.110 & 0.392 \\
\hline 29 & Ethiopia & 0.955 & 0.000 & 0.003 & 0.914 & 0.083 & 0.391 \\
\hline 30 & Nepal & 1.000 & 0.001 & 0.005 & 0.865 & 0.079 & 0.390 \\
\hline 31 & Zambia & 0.918 & 0.004 & 0.013 & 0.910 & 0.082 & 0.386 \\
\hline 32 & Bolivia & 0.929 & 0.142 & 0.062 & 0.586 & 0.207 & 0.385 \\
\hline 33 & Tanzania & 0.952 & 0.001 & 0.007 & 0.874 & 0.082 & 0.383 \\
\hline 34 & $\begin{array}{l}\text { Dominican } \\
\text { Republic }\end{array}$ & 0.713 & 0.425 & 0.156 & 0.586 & 0.019 & 0.380 \\
\hline 35 & Myanmar & 0.998 & 0.014 & 0.001 & 0.717 & 0.134 & 0.373 \\
\hline 36 & Morocco & 0.581 & 0.343 & 0.104 & 0.816 & 0.002 & 0.369 \\
\hline 37 & Cambodia & 0.941 & 0.008 & 0.048 & 0.710 & 0.063 & 0.354 \\
\hline
\end{tabular}




\begin{tabular}{|c|c|c|c|c|c|c|c|}
\hline 38 & Sudan & 0.853 & 0.035 & 0.009 & 0.664 & 0.202 & 0.353 \\
\hline 39 & Ghana & 0.860 & 0.041 & 0.025 & 0.743 & 0.068 & 0.347 \\
\hline 40 & Cameroon & 0.941 & 0.012 & 0.009 & 0.653 & 0.115 & 0.346 \\
\hline 41 & El Salvador & 0.808 & 0.151 & 0.075 & 0.641 & 0.055 & 0.346 \\
\hline 42 & Zimbabwe & 0.949 & 0.008 & 0.032 & 0.644 & 0.080 & 0.343 \\
\hline 43 & Philippines & 0.807 & 0.226 & 0.034 & 0.561 & 0.053 & 0.336 \\
\hline 44 & Cote d'Ivoire & 0.770 & 0.009 & 0.016 & 0.771 & 0.103 & 0.334 \\
\hline 45 & Botswana & 0.879 & 0.402 & 0.044 & 0.288 & 0.040 & 0.330 \\
\hline 46 & Indonesia & 0.895 & 0.135 & 0.079 & 0.373 & 0.158 & 0.328 \\
\hline 47 & Benin & 0.865 & 0.018 & 0.074 & 0.626 & 0.050 & 0.327 \\
\hline 48 & China & 0.843 & 0.501 & 0.100 & 0.091 & 0.083 & 0.324 \\
\hline 49 & Vietnam & 0.966 & 0.078 & 0.059 & 0.361 & 0.108 & 0.314 \\
\hline 50 & Kenya & 0.633 & 0.004 & 0.014 & 0.809 & 0.074 & 0.307 \\
\hline 51 & Togo & 0.591 & 0.008 & 0.016 & 0.841 & 0.074 & 0.306 \\
\hline 52 & Honduras & 0.860 & 0.103 & 0.031 & 0.455 & 0.043 & 0.298 \\
\hline 53 & South Africa & 0.743 & 0.572 & 0.072 & 0.000 & 0.100 & 0.298 \\
\hline 54 & Sri Lanka & 0.813 & 0.098 & 0.020 & 0.503 & 0.048 & 0.296 \\
\hline 55 & Guatemala & 0.837 & 0.093 & 0.030 & 0.462 & 0.054 & 0.295 \\
\hline 56 & Bangladesh & 0.839 & 0.051 & 0.029 & 0.483 & 0.075 & 0.295 \\
\hline 57 & Nicaragua & 0.763 & 0.068 & 0.021 & 0.500 & 0.048 & 0.280 \\
\hline 58 & Jamaica & 0.636 & 0.271 & 0.072 & 0.380 & 0.013 & 0.274 \\
\hline 59 & India & 0.832 & 0.131 & 0.048 & 0.232 & 0.066 & 0.262 \\
\hline 60 & Senegal & 0.770 & 0.046 & 0.021 & 0.418 & 0.037 & 0.258 \\
\hline 61 & Pakistan & 0.245 & 0.058 & 0.088 & 0.490 & 0.067 & 0.190 \\
\hline 62 & Haiti & 0.000 & 0.011 & 0.003 & 0.678 & 0.064 & 0.151 \\
\hline
\end{tabular}


Table A3: Comparison of SEDI ranking with other indicators

\begin{tabular}{|c|c|c|c|c|c|c|c|}
\hline \multicolumn{2}{|l|}{ SEDI } & \multicolumn{2}{|c|}{ HDI } & \multicolumn{2}{|c|}{ EDI } & \multicolumn{2}{|c|}{ EPI } \\
\hline \multicolumn{8}{|c|}{ VERY HIGH PERFORMERS } \\
\hline Iran & 0.707 & Argentina & 0.797 & Libya & 0.923 & Costa Rica & 0.690 \\
\hline Argentina & 0.671 & Uruguay & 0.783 & Iran & 0.889 & Malaysia & 0.625 \\
\hline Libya & 0.638 & Cuba & 0.776 & Lebanon & 0.850 & Colombia & 0.623 \\
\hline Algeria & 0.593 & Panama & 0.768 & Venezuela & 0.844 & Brazil & 0.609 \\
\hline Venezuela & 0.575 & Malaysia & 0.761 & Argentina & 0.798 & Ecuador & 0.606 \\
\hline Jordan & 0.505 & Libya & 0.760 & Jordan & 0.773 & Thailand & 0.600 \\
\hline Congo & 0.500 & Costa Rica & 0.744 & Malaysia & 0.741 & Nicaragua & 0.592 \\
\hline Gabon & 0.496 & Lebanon & 0.739 & Algeria & 0.706 & Nepal & 0.580 \\
\hline Ecuador & 0.488 & Venezuela & 0.735 & Syria & 0.703 & Panama & 0.579 \\
\hline Malaysia & 0.487 & Jamaica & 0.727 & Uruguay & 0.692 & Gabon & 0.579 \\
\hline Colombia & 0.486 & Peru & 0.725 & South Africa & 0.681 & Philippines & 0.574 \\
\hline Angola & 0.483 & Ecuador & 0.720 & Egypt & 0.668 & Uruguay & 0.571 \\
\hline Brazil & 0.471 & Brazil & 0.718 & Costa Rica & 0.616 & Argentina & 0.565 \\
\hline Syria & 0.471 & Colombia & 0.710 & Brazil & 0.590 & Cuba & 0.565 \\
\hline Egypt & 0.471 & Iran & 0.707 & Cuba & 0.581 & Sri Lanka & 0.557 \\
\hline Costa Rica & 0.467 & Tunisia & 0.698 & Ecuador & 0.563 & Venezuela & 0.556 \\
\hline \multicolumn{8}{|c|}{ HIGH PERFORMERS } \\
\hline Lebanon & 0.458 & Jordan & 0.698 & Mongolia & 0.550 & Zambia & 0.556 \\
\hline Yemen & 0.440 & Algeria & 0.698 & Thailand & 0.547 & Cambodia & 0.553 \\
\hline Uruguay & 0.426 & Sri Lanka & 0.691 & China & 0.547 & Egypt & 0.552 \\
\hline Cuba & 0.415 & $\begin{array}{l}\text { Dominican } \\
\text { Republic }\end{array}$ & 0.689 & Morocco & 0.532 & Bolivia & 0.546 \\
\hline Panama & 0.413 & China & 0.687 & Colombia & 0.528 & Jamaica & 0.544 \\
\hline Paraguay & 0.410 & Thailand & 0.682 & Panama & 0.517 & Tanzania & 0.543 \\
\hline Nigeria & 0.407 & El Salvador & 0.674 & $\begin{array}{l}\text { Dominican } \\
\text { Republic }\end{array}$ & 0.515 & Botswana & 0.537 \\
\hline Tunisia & 0.407 & Gabon & 0.674 & Tunisia & 0.498 & Cote d'Ivoire & 0.536 \\
\hline Mongolia & 0.402 & Paraguay & 0.665 & Jamaica & 0.490 & Zimbabwe & 0.528 \\
\hline Peru & 0.397 & Bolivia & 0.663 & Paraguay & 0.480 & Myanmar & 0.527 \\
\hline Thailand & 0.393 & Mongolia & 0.653 & Bolivia & 0.397 & Ethiopia & 0.527 \\
\hline Mozambique & 0.392 & Philippines & 0.644 & Peru & 0.390 & Honduras & 0.525 \\
\hline Ethiopia & 0.391 & Egypt & 0.644 & Philippines & 0.383 & $\begin{array}{l}\text { Dominican } \\
\text { Republic }\end{array}$ & 0.524 \\
\hline Nepal & 0.390 & Botswana & 0.633 & Vietnam & 0.381 & Paraguay & 0.524 \\
\hline Zambia & 0.386 & Syria & 0.632 & Yemen & 0.378 & Indonesia & 0.523 \\
\hline Bolivia & 0.385 & Honduras & 0.625 & El Salvador & 0.361 & El Salvador & 0.521 \\
\hline \multicolumn{8}{|c|}{ MODERATE PERFORMERS } \\
\hline Tanzania & 0.383 & South Africa & 0.619 & Indonesia & 0.297 & Guatemala & 0.519 \\
\hline $\begin{array}{l}\text { Dominican } \\
\text { Republic }\end{array}$ & 0.380 & Indonesia & 0.617 & India & 0.294 & Vietnam & 0.506 \\
\hline Myanmar & 0.373 & Vietnam & 0.593 & Honduras & 0.285 & Benin & 0.504 \\
\hline
\end{tabular}




\begin{tabular}{|c|c|c|c|c|c|c|c|}
\hline Morocco & 0.369 & Nicaragua & 0.589 & Guatemala & 0.284 & Peru & 0.503 \\
\hline Cambodia & 0.354 & Morocco & 0.582 & Botswana & 0.280 & Kenya & 0.493 \\
\hline Sudan & 0.353 & Guatemala & 0.574 & Pakistan & 0.270 & Togo & 0.487 \\
\hline Ghana & 0.347 & India & 0.547 & Sri Lanka & 0.258 & Algeria & 0.486 \\
\hline Cameroon & 0.346 & Ghana & 0.541 & Nicaragua & 0.241 & Mozambique & 0.478 \\
\hline El Salvador & 0.346 & Congo & 0.533 & Gabon & 0.230 & Angola & 0.476 \\
\hline Zimbabwe & 0.343 & Cambodia & 0.523 & Ghana & 0.193 & Ghana & 0.475 \\
\hline Philippines & 0.336 & Kenya & 0.509 & Zimbabwe & 0.175 & Lebanon & 0.474 \\
\hline Cote d'Ivoire & 0.334 & Pakistan & 0.504 & Bangladesh & 0.168 & Congo & 0.472 \\
\hline Botswana & 0.330 & Bangladesh & 0.500 & Senegal & 0.156 & Senegal & 0.467 \\
\hline Indonesia & 0.328 & Angola & 0.486 & Cote d'Ivoire & 0.135 & Tunisia & 0.467 \\
\hline Benin & 0.327 & Myanmar & 0.483 & Nigeria & 0.134 & Sudan & 0.460 \\
\hline China & 0.324 & Cameroon & 0.482 & Cameroon & 0.130 & Morocco & 0.458 \\
\hline \multicolumn{8}{|c|}{ WEAK PERFORMERS } \\
\hline Vietnam & 0.314 & Tanzania & 0.466 & Congo & 0.120 & Mongolia & 0.454 \\
\hline Kenya & 0.307 & Yemen & 0.462 & Benin & 0.110 & Cameroon & 0.430 \\
\hline Togo & 0.306 & Senegal & 0.459 & Sudan & 0.110 & Syria & 0.428 \\
\hline Honduras & 0.298 & Nigeria & 0.459 & Angola & 0.110 & Iran & 0.427 \\
\hline South Africa & 0.298 & Nepal & 0.458 & Nepal & 0.102 & Bangladesh & 0.426 \\
\hline Sri Lanka & 0.296 & Haiti & 0.454 & Haiti & 0.093 & China & 0.422 \\
\hline Guatemala & 0.295 & Togo & 0.435 & Cambodia & 0.081 & Jordan & 0.422 \\
\hline Bangladesh & 0.295 & Zambia & 0.430 & Zambia & 0.074 & Haiti & 0.412 \\
\hline Nicaragua & 0.280 & Benin & 0.427 & Togo & 0.053 & Nigeria & 0.401 \\
\hline Jamaica & 0.274 & Sudan & 0.408 & Kenya & 0.037 & Pakistan & 0.396 \\
\hline India & 0.262 & Cote d'Ivoire & 0.400 & Tanzania & 0.022 & Libya & 0.377 \\
\hline Senegal & 0.258 & Zimbabwe & 0.376 & Myanmar & 0.018 & India & 0.362 \\
\hline Pakistan & 0.190 & Ethiopia & 0.363 & Ethiopia & 0.017 & Yemen & 0.355 \\
\hline Haiti & 0.151 & Mozambique & 0.322 & Mozambique & 0.013 & South Africa & 0.346 \\
\hline
\end{tabular}

